University of Baltimore Law

ScholarWorks@University of Baltimore

School of Law

ScholarWorks@University of

Baltimore School of Law

All Faculty Scholarship

Faculty Scholarship

8-2021

\title{
Climate and transportation policy sequencing in California and Quebec
}

\author{
Sonya Ziaja \\ University of Baltimore School of Law, sziaja@ubalt.edu \\ Mark Purdon \\ purdon.mark@uqam.ca \\ Julie Witcover \\ Colin Murphy \\ Mark Winfield
}

See next page for additional authors

Follow this and additional works at: https://scholarworks.law.ubalt.edu/all_fac

Digitart of the Law Commons, and the Natural Resources Management and Policy Commons

Commons

Network

Recommended Citation

Sonya Ziaja, Mark Purdon, Julie Witcover, Colin Murphy, Mark Winfield, Genevieve Giuliano, Charles

Séguin, Colleen Kaiser, Jacques Papy \& Lewis Fulton, Climate and transportation policy sequencing in California and Quebec, 38 Review of Policy Research 1 (2021).

Available at: https://scholarworks.law.ubalt.edu/all_fac/1123

This Article is brought to you for free and open access by the Faculty Scholarship at ScholarWorks@University of Baltimore School of Law. It has been accepted for inclusion in All Faculty Scholarship by an authorized administrator of ScholarWorks@University of Baltimore School of Law. For more information, please contact hmorrell@ubalt.edu. 


\section{Authors}

Sonya Ziaja, Mark Purdon, Julie Witcover, Colin Murphy, Mark Winfield, Genevieve Giuliano, Charles Séguin, Colleen Kaiser, Jacques Papy, and Lewis Fulton 


\title{
Climate and transportation policy sequencing in California and Quebec
}

\author{
Mark Purdon $^{1}$ | Julie Witcover ${ }^{2,3}$ | Colin Murphy ${ }^{3}$ | \\ Sonya Ziaja $^{4}$ | Mark Winfield ${ }^{5}$ | Genevieve Giuliano ${ }^{6}$ \\ Charles Séguin $^{7} \mid$ Colleen Kaiser $^{8}$ | Jacques Papy ${ }^{9}$ | Lewis Fulton ${ }^{2}$
}

${ }^{1}$ Département de stratégie, responsabilité sociale et environnementale \& Chaire sur la décarbonisation, École des sciences de la gestion (ESG), Université du Québec à Montréal (UQAM), Montreal, QC, Canada

${ }^{2}$ Institute of Transportation Studies, University of California Davis, Davis, CA, USA

${ }^{3}$ Policy Institute for Energy,

Environment, and the Economy, University of California Davis, Davis, CA, USA

${ }^{4}$ University of Baltimore School of Law, Baltimore, MA, USA

${ }^{5}$ Faculty of Environmental and Urban Change (EUC), York University, Toronto, ON, Canada

${ }^{6}$ University of Southern California, Sol Price School of Public Policy, Los Angeles, CA, USA

${ }^{7}$ Département des sciences économiques, École des sciences de la gestion (ESG),

Université du Québec à Montréal (UQAM), Montreal, QC, Canada

${ }^{8}$ Smart Prosperity Institute, University of Ottawa, Ottawa, ON, Canada

${ }^{9}$ Faculté de sciences politique et de droit, Université du Québec à Montréal (UQAM), Montreal, QC, Canada

\begin{abstract}
We compare flexible low-carbon regulations in the transportation sector and their interaction and sequencing with greenhouse gas emissions trading systems in California and Quebec. As momentum builds for greater climate action, it is necessary to better understand how carbon markets and other low-carbon transportation policies influence one another. First, we demonstrate that emissions trading between California and Quebec has been asymmetric, with linking having little influence on carbon prices from California's perspective but leading to a considerable cost reduction from the point of view of Quebec. Second, we present evidence that Quebec has replicated many of California's low-carbon transportation policies that promote increased electric vehicle use, where Quebec has an advantage, while deferring to the Canadian federal government with regard to policies that incentivize the production of other lowcarbon transportation fuels. Third, we demonstrate that while the stringency of the policy mix of carbon pricing and flexible transportation regulations has increased over time in both jurisdictions, the stringency of flexible
\end{abstract}




\section{Correspondence}

Mark Purdon, Département de stratégie, responsabilité sociale et environnementale, Chaire sur la décarbonisation, École des sciences de la gestion, Université du Québec à Montréal (UQAM), 315, rue Sainte-Catherine Est, Montréal, QC H2X 3X2, Canada.

Email: purdon.mark@uqam.ca

\section{Funding information}

Social Sciences and Humanities Research Council of Canada, Grant/Award Number: 890-2017-0059; Sustainable Transportation and Energy Pathways (STEPS) Program; Policy Institute for Energy, Environment, and the Economy, UC Davis regulations has been more aggressively ratcheted up and is expected to continue to dominate. Overall, our findings suggest that the policy sequence observed in California and Quebec can be attributed to the political economy benefits that the selected instruments confer to governments seeking to move from the middle towards the bottom of the clean technology experience curve. We discuss a number of important research questions and associated hypotheses emanating from our findings, which provide the basis for more in-depth studies involving a larger universe of cases and economic sectors.

\section{K E Y W O R D S}

California, climate policy, emissions trading, low-carbon transportation, policy sequencing, Quebec

\section{INTRODUCTION}

In this paper, we compare flexible low-carbon regulations in the transportation sector and their interaction and sequencing with greenhouse gas (GHG) emissions trading systems in California and Quebec. Since 2014 Quebec has been linked to California's emissions trading system under the auspices of the Western Climate Initiative (WCI) (Cloarec \& Purdon, 2018; Cullenward \& Victor, 2020; Houle et al., 2015; Rabe, 2018; Roch \& Papy, 2019). Comparison of California and Quebec is important because, unlike other emissions trading systems, including the European Union Emissions Trading Scheme (EU-ETS) and the Regional Greenhouse Gas Initiative (RGGI) in the northeast United States, the WCI targets a broad range of sectors, including liquid transportation fuels. Yet while collective GHG emissions in California and Quebec have declined, road transport emissions have, until very recently, been rising gradually and represent the largest sectoral share in each jurisdiction (Figure 1).

To achieve transportation sector emissions reductions, it is necessary to understand how carbon markets and other low-carbon transportation policies influence the implementation and efficacy of one another. Discussion of the relationship between the two has tended to settle on terms of "policy sequencing" and "policy mixes" (Axsen et al., 2020; Bhardwaj et al., 2020; Meckling et al., 2017; Pahle et al., 2018). However, as organizers of a recent workshop on carbon pricing and innovation concluded, further empirical investigation into policy sequencing, particularly at the sectoral level, is necessary (Jenkins et al., 2020, p. 22).

Our study contributes to this discussion by asking what policy tools have the governments of California and Quebec used to tackle emissions in the transportation sector, in what sequence have they been deployed and what is their relationship with emissions trading? We focus on emissions trading as well as one particularly important set of low-carbon policies-flexible lowcarbon regulatory instruments in the transportation sector. These are policy instruments that 


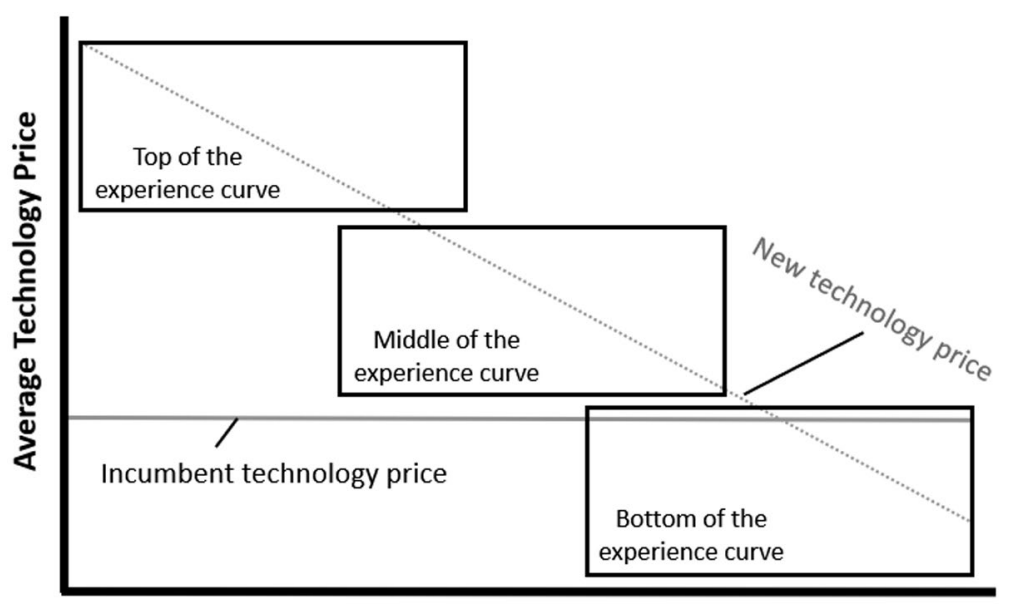

Cumulative Technology Capacity Produced

F I G U R E 1 Three stages of a stylized clean technology experience curve. Source: Adapted from Breetz et al. (2018)

"focus on a market-wide outcome without dictating the specific behavioral or technological choices in individuals and firms" (Jaccard, 2020, p. 110).

For over a decade, such regulations have played a dominant role in California's plans to reduce emissions through 2030 across sectors, though the expected contribution of cap-and-trade to emission reductions has increased from 20\% for 2013-2020 to 38\% for the period 2021-2030 (CARB, 2008, p. 17, 2017a, pp. 26-28). In California's transportation sector, flexible regulations are generally recognized to include instruments such as vehicle emissions standards, zero emissions vehicle (ZEV) mandates, and the low carbon fuel standard (LCFS). We also include "regional plan climate targets" as a planning instrument to reduce metropolitan transportation emissions in an integrative yet flexible manner. While there are certainly other instruments that are part of California's complex suite of climate policies, such as subsidies for ZEVs and related infrastructure, public procurement policies and research and development initiatives, they are beyond the scope of our study.

With attention to the sequencing of carbon pricing and flexible regulations in California and Quebec transportation sectors, this paper's findings raise important research questions and associated hypotheses, providing a foundation for more in-depth studies. Our research also addresses a gap in California climate policy literature by offering policy details on its relationship with Quebec, which continues to be its sole partner in emissions trading.

First, we demonstrate that emissions trading between California and Quebec has been asymmetric, with linking having little influence on carbon prices from California's perspective but leading to a considerable cost reduction from the point of view of Quebec, which has fewer low-cost abatement opportunities in the energy sector. Second, we present evidence that Quebec has replicated many of California's low-carbon transportation policies that promote increased electric vehicle use, where Quebec has an advantage due to its low-carbon electricity grid, while deferring to the Canadian federal government with regard to policies that incentivize the production of other low-carbon transportation fuels such as biofuels. Third, we demonstrate that while the stringency of the policy mix of carbon pricing and flexible transportation regulations has increased over time in both jurisdictions, the stringency of flexible regulations has been more aggressively ratcheted up and is expected to continue to dominate. 
The paper proceeds as follows. We first present our theoretical and methodological approach, which is characterized by its focus on policy instruments as "tools of government" (Hood \& Margetts, 2007; Salamon, 2002). This is followed by a brief comparison of the economic conditions in California and Quebec. Third, we review the history and performance of emissionstrading in California and Quebec before summarizing recent research suggesting that low carbon prices on the California carbon market are structural features partially related to flexible regulations themselves. We then provide a comparative review of the evolution of low-carbon flexible regulations in the two transportation sectors, following a convention to distinguish between vehicle fleet decarbonization, transportation fuel decarbonization and transportation demand management. In the discussion we present important research questions and hypotheses prompted by our findings as well as alternative hypotheses. Overall, our findings suggest that the policy sequence observed in California and Quebec can be attributed to the political economy benefits that the selected instruments confer to governments seeking to move from the middle towards the bottom of the clean technology experience curve.

\section{THEORETICAL AND METHODOLOGICAL APPROACH}

Economists have traditionally advocated carbon pricing as a key instrument for climate mitigation (Ecofiscal Commission, 2019; High-Level Commission on Carbon Prices, 2017; van den Bergh \& Botzen, 2020). Many have also raised concerns about whether and how low-carbon regulatory instruments might distort carbon pricing and undermine its primary goals (Bennear \& Stavins, 2007; Böhringer \& Rosendahl, 2010; Fischer \& Preonas, 2010; Fischer et al., 2017; Schatzki \& Stavins, 2018a). Other economists are more favorable to such interactions (Baranzini et al., 2017; Jaccard, 2020).

In the political science literature, the interaction between carbon pricing and regulations is more ambiguous. One position anticipates carbon pricing will prevail after other regulatory instruments first succeed in driving down the costs of low-carbon technologies. For example, drawing on cases prior to 2014, Meckling and colleagues demonstrate that green industrial policy-a suite of policy instruments that include flexible regulations-has often been introduced prior to carbon pricing, with the stringency of the policy mix being increased over time (Meckling, 2017; Meckling et al., 2015). Similarly, Breetz et al. (2018) present a typology of clean energy transitions that distinguishes between different political logics at the beginning, middle and late stages of the clean technology experience curve. See Figure 1. Experience curves have been developed by economists as a way of modeling how the costs of new technology decline over time as actors gain experience with how to produce and deploy it more efficiently (Rubin et al., 2015; Weiss et al., 2010). The contribution of Breetz et al. (2018) has been to highlight how different political obstacles and opportunities might emerge at different levels of the clean technology experience curve and that "global energy systems are not on an inexorable, market-driven path to clean energy” (p. 493).

For example, while authors present California's ZEV mandate as an example of a policy instrument at the top of the experience curve, they are more equivocal about the position of other flexible regulations in the transportation sector as well as carbon pricing. To the extent that it is mentioned, carbon pricing is expected to be more salient towards the bottom of the experience curve, though the authors note that, since there are few jurisdictions at this level of the experience curve, "[t]his is the new frontier of energy policy making” (p. 515). Various authors have also identified revenue raised through carbon pricing as an important policy feedback mechanism 
(Klenert et al., 2018; Rabe, 2018), which would also suggest a role for emissions trading at the initial stages of the experience curve.

Another position in the political science literature is reflected in Cullenward and Victor (2020), who remain highly skeptical of the role of carbon markets. They argue that carbon markets will play a much narrower role moving forward because of political challenges that linking emissions trading systems introduce, particularly between jurisdictions whose abatement costs differ considerably. The most important political challenge is triggered by capital outflows as firms chase lowest cost mitigation opportunities abroad that risk negatively affecting powerful, incumbent interest groups. Such political challenges limit followership via the linkage of emissions trading. Importantly, Cullenward and Victor suggest that the linkage between California and Quebec carbon markets was feasible and did not trigger such concerns because it has been comprised of "programs with similar prices and nearly identical program designs" (pp. 106-108). A related explanation for limited followership incited by emissions trading is policy capacity. This might be defined as a set of competences and capabilities at different levels of governance necessary to perform policy functions (Wu et al., 2015). For example, concerns have been raised about whether policy capacity constraints have limited the replication of California's complex suite of climate policy instruments elsewhere (Bang et al., 2017).

The methodology of our study corresponds to what Peters and Zittoun (2016) have described as the "policy analysis" approach in political science, given our focus on policy instruments. More specifically we adopt a "tools of government" methodology to investigate the sequencing of emissions trading and flexible transportation sector regulations through 2030 (Hood \& Margetts, 2007; Salamon, 2002). We supplement this with technical analysis of certain instruments. The "tools of government" approach recognizes that the selection of policy instruments from the vast array of tools available is itself politically salient (Hood \& Margetts, 2007, p. 148). It also recognizes that certain policy tools will perform better in one particular context than another. Finally, with regard to policy capacity, our comparative case-study of California and Quebec constitutes a "least likely" critical case (see Flyvbjerg, 2006) given that it is widely recognized that California possesses exceptional policy capacity (Rabe, 2018).

Our methodological approach contrasts with more detailed research into the policy process, a second approach identified by Peters and Zittoun (2016). For example, the study of Breetz et al. (2018) and other recent studies of clean energy transitions in North America and European have demonstrated that considerable insights might be derived through comparative process tracing methods (Breetz, 2017; Rabe, 2018; Stokes, 2020; Stokes \& Breetz, 2018). Though we see tremendous value in process tracing methods, an approach that focuses on policy instruments has certain advantages. Most importantly, it allows us to better document and understand the sequence of a range of policy instruments and their interaction in two different jurisdictions.

There are limitations to the tools approach. It does not lend itself to understanding the decision-making process and, consequently, cannot speak with confidence to the motivations of state and non-state actors involved. Indeed, there is a proclivity in the tools-based approach of "treating government as a totality" (Hood \& Margetts, 2007, p. 15). Consequently, our approach reserves language that imputes government motivation to the discussion. Similarly, despite being a "least likely" critical case of policy capacity, a study limited to policy tools adopted by California and Quebec is unable to explain why jurisdictions other than Quebec have not also taken steps to link with California's carbon market. While we offer some description of government institutions in both jurisdictions, we do not measure policy capacity, which would require deeper probing. Rather, we see this paper as a preliminary and complementary step to more detailed research using comparative process tracing to investigate a wider universe of cases. 


\section{CONTEXTUAL FACTORS IN CALIFORNIA AND QUEBEC}

In many ways, California and Quebec are quite different. California is one of the world's largest economies and its population and GHG emissions are five times greater than those of Quebec. Additional information on basic economic, demographic, and climate policy characteristics of California and Quebec can be found in Table 1.

As has already been suggested, California is recognized to have outstanding policy capacity in the environmental field. California relies on the California Air Resources Board (CARB), an executive agency, to implement air quality goals set by the California state legislature and also provide resources for coordinating the WCI (Collantes \& Sperling, 2008; Meckling \& Nahm, 2018; Rabe, 2018). While CARB has broad authority over emissions trading and many low-carbon transportation policy instruments, regulation of the energy sector is led by the California Energy Commission, California Public Utilities Commission, and the California Independent System Operator. In Quebec, the Ministère de l'Environnement et de la Lutte contre les changements climatiques (MELCC) is responsible for emissions trading. However, the Ministère des Transports (MTQ) and the Ministère de l'Énergie et des Ressources naturelles (MERN) have lead authority over transportation and energy policy, respectively. While Quebec is building policy capacity for low-carbon regulations, we submit that this is far surpassed by that in California.

Another important difference between California and Quebec is with regard to energy supply and, thus, marginal emissions abatement opportunities. Quebec's energy sector is among the lowest GHG-emitting in North America, with hydroelectricity currently meeting 36\% of the province's total energy demand (Whitmore \& Pineau, 2018, p. 29). Quebec also possesses the lowest electricity prices anywhere in North America (Hydro-Québec, 2018). In 2018, emissions per capita in Quebec stood at 9.6 tCO2e, slightly cleaner than California's 10.8 tCO2e (CARB, 2019a; ECCC, 2019b).

Despite the above differences, California and Quebec share certain political characteristics. Existing research has attributed California and Quebec's perseverance with cap-and-trade to similarities in terms of ideas, namely, belief in climate science and confidence in a slightly more interventionist political economy orientation, in addition to relatively fewer carbon intensive industries (Houle et al., 2015). Quebec has even gone so far as to place a moratorium on all oil and gas exploration-something which California has only partially been able to achieve (McCrary et al., 2003; Rabe, 2018). California was the seventh largest state producing oil in 2020, representing 3.5\% total US production (EIA, 2021) — though in April 2021 Governor Newsom announced the start of efforts to phase out new gas and oil production by 2045 (Reuters, 2021).

\section{CALIFORNIA AND QUEBEC'S EXPERIENCE WITH EMISSIONS TRADING}

\section{History of cap-and-trade}

California's emissions trading system has been discussed extensively and we point the interested reader to other publications for detailed accounts (Bang et al., 2017; Cullenward \& Victor, 2020; Houle et al., 2015; Rabe, 2018). Briefly, California launched its emissions trading system in late 2012, after passage of the 2006 California Global Warming Solutions Act where the state committed to reducing emissions to 1990 levels by 2020 (Assembly Bill 32, “AB32”). While AB32 set an emission reduction target, it did not set the means of achieving it. Emissions trading prevailed 
TA B LE 1 Economic, demographic, and climate policy features of California and Quebec

\begin{tabular}{|c|c|c|}
\hline Item & California & Quebec \\
\hline $\begin{array}{l}\text { GDP } 2018 \text { (\$ million USD, } 2012 \text { chained } \\
\text { dollars) }\end{array}$ & $\$ 2,721,556$ & $\$ 280,645$ \\
\hline Population 2018 (million) & 39.5 & 8.4 \\
\hline GDP per capita 2018 (\$ million USD) & $\$ 68,970$ & $\$ 33,458$ \\
\hline Emissions 1990 (MtCO2e) & 427 & 86 \\
\hline Emissions 2018 (MtCO2e) & 425 & 81 \\
\hline Emissions per capita 2018 (MtCO2e) & 10.8 & 9.6 \\
\hline $\begin{array}{l}\text { Emissions intensity } 2018 \text { (MtCO2e/\$GDP } \\
\text { billion USD) }\end{array}$ & 0.16 & 0.29 \\
\hline $\begin{array}{l}\text { Emissions from road transportation } 2018 \\
\quad(\%)\end{array}$ & $36.3 \%$ & $35.6 \%$ \\
\hline 2020 Emissions reduction target & 1990 levels & 20\% below 1990 levels \\
\hline 2030 Emissions reduction target & 40\% below 1990 levels & $37.5 \%$ below 1990 levels \\
\hline Price of electricity 2018-residential & 21.8థUS/kWh (San Francisco) & 5.6థUS/kWh (Montreal) \\
\hline $\begin{array}{l}\text { Price of electricity 2018-large-power } \\
\text { customers }\end{array}$ & 11.6థUS/kWh (San Francisco) & 4.0£US/kWh (Montreal) \\
\hline
\end{tabular}

Source: Authors' calculations, Hydro-Québec (2018).

over alternative carbon pricing mechanism largely because of administrative and political hurdles involved with adopting a carbon tax (Cullenward \& Victor, 2020; Houle et al., 2015). However, the full suite of California's climate strategy is laid out in so-called "Scoping Plans", the first for the 2013-2020 period having been introduced in 2008 (CARB, 2008). In 2016, California's legislature committed to reducing the state's emissions to $40 \%$ below the 1990 levels by 2030 (CARB, 2017c; Diodati \& Purdon, 2016). California's cap-and-trade system was subsequently extended through 2030 by way of adoption of Assembly Bill 398 (AB398) in mid-2017 while the Scoping Plan for 2021-2030 was adopted in late 2017 (CARB, 2017d).

Quebec launched its own emissions trading system in 2013 under the WCI, linking its market with California's in 2014. Quebec set a more ambitious 2020 emission reduction target than California, at 20\% below 1990 levels. However, the government adopted a target of $37.5 \%$ below 1990 levels for 2030 - slightly less ambitious than California but adopted in 2015 during a period of considerable uncertainty about the future of the state's climate policy (Diodati \& Purdon, 2016; La Presse, 2015). California and Quebec base their linked cap-and-trade on a voluntary administrative agreement between the two governments, the Agreement on the Harmonization and Integration of Cap-and-Trade Programs for Reducing Greenhouse Gas Emissions (Roch \& Papy, 2019; Trudeau, 2018). Quebec confirmed the extension of the carbon market and its linkage with California's during negotiations in 2017 with Ontario about its entry (Carmody, 2019, pp. 42-44). However, as is well known, Ontario withdrew from the carbon market after the June 2018 election resulted in a populist government strongly opposed to emissions trading (Cloarec \& Purdon, 2018; Lachapelle \& Kiss, 2019).

One of the important innovations of the California-Quebec carbon market was a carbon price floor and ceiling. This responded to concerns about price stability and oversupply that had plagued the early stages of the EU-ETS (Ellerman et al., 2010). In 2013, California and Quebec 
agreed to an initial auction floor price of \$10 USD per tCO2e, which increases by 5\% annually plus the rate of inflation, reaching \$17.71 USD in 2021. Interestingly, Quebec originally sought a 7\% annual rate of increase for the price floor (Purdon et al., 2014). California and Quebec also established a price ceiling, though its form has changed. For 2013-2020, an Allowance Price Containment Reserve (APCR), administered independently by each jurisdiction, was used to collect a portion of allowances auctioned each year, which were set aside for potential release to deflate a sudden price surge. But the APCR might be depleted if prices reached too high. Consequently, for the post-2021 period, California has set a firm price ceiling starting at \$65 USD per tCO2e in 2021, which also increases annually by $5 \%$ plus the rate of inflation (Busch, 2017; CARB, 2019d, §95915(f)). Based on these rates of increase, prices on the California-Quebec carbon market are expected to gradually rise between a price floor and price ceiling reaching approximately \$27 and \$101 USD (\$36 to \$128 CDN), respectively.

California and Quebec's separate emission trading systems each generate substantial government revenues through quarterly auction of emission allowances. In California, cap-and-trade auctions have generated $\$ 14.9$ billion for the Greenhouse Gas Reduction Fund (GGRF) to date (CCI, 2021). In Quebec, revenue generated from auction allowances have been deposited in a Green Fund, which has recently the target of reforms and given the new name of the Electrification and Climate Change Fund (CGFV, 2018; Fletcher, 2019). Auction proceeds amounted to approximately \$3.4 billion USD ( $\$ 4.3$ billion CDN) over 2013-2020 (MELCC, 2020a), of which over 86\% was allocated to climate actions under the 2013-2020 Climate Change Action Plan (MDDELCC, 2018, p. 9). The Quebec government's recently announced 2030 Plan for a Green Economy also relies in an "important way"1 on the funds derived from the carbon market (Gouvernement du Québec, 2020b, p. 100).

Significantly, the Quebec emissions trading system preceded the 2016 introduction of the Canadian federal government's Pan-Canadian Framework on Clean Growth and Climate Change (Government of Canada, 2016). This applies a carbon pricing "backstop" for provinces unwilling or unable to implement a carbon pricing policy of their own. As originally presented, the Canadian federal carbon backstop price was slated to rise from \$8 to \$39 USD over the period 2018 to 2022 ( $\$ 10$ to $\$ 50 \mathrm{CDN}$ ). As recently as 2019 the federal government announced there were no plans to raise prices further (McCarthy \& Giovannetti, 2019). However, in late 2020 the Canadian federal government proposed to increase the federal carbon price to approximately \$134 USD per tCO2e by 2030 ( $\$ 170 \mathrm{CDN}$ ) (ECCC, 2020, p. 26). The federal carbon price is currently not applied in Quebec, until a federal review in 2022 determines if Quebec's system is equivalent to federal criteria, under yet-to-be decided equivalency metrics (Government of Canada, 2018; Kyriazis, 2017; Mascher, 2018). We also note that the Canadian federal government's 2030 commitment of reducing GHG emissions 30\% below 2005 levels_or approximately 13\% below 1990 levels—is considerably less ambitious than that found in California and Quebec.

\section{Emission trends, prices and trading}

In this section we provide an overview of trends in emissions, carbon market prices and emissions trading on the California-Quebec carbon market to date.

First, drawing on information reported in annual emission inventories for each jurisdiction, we find total emissions between California and Quebec to be declining-even prior to the global pandemic_despite a slight increase in transport emissions from 2010 to 2017 (Figure 2). Due to significant emission reductions in California's power sector, in part attributed to the 2008 global 


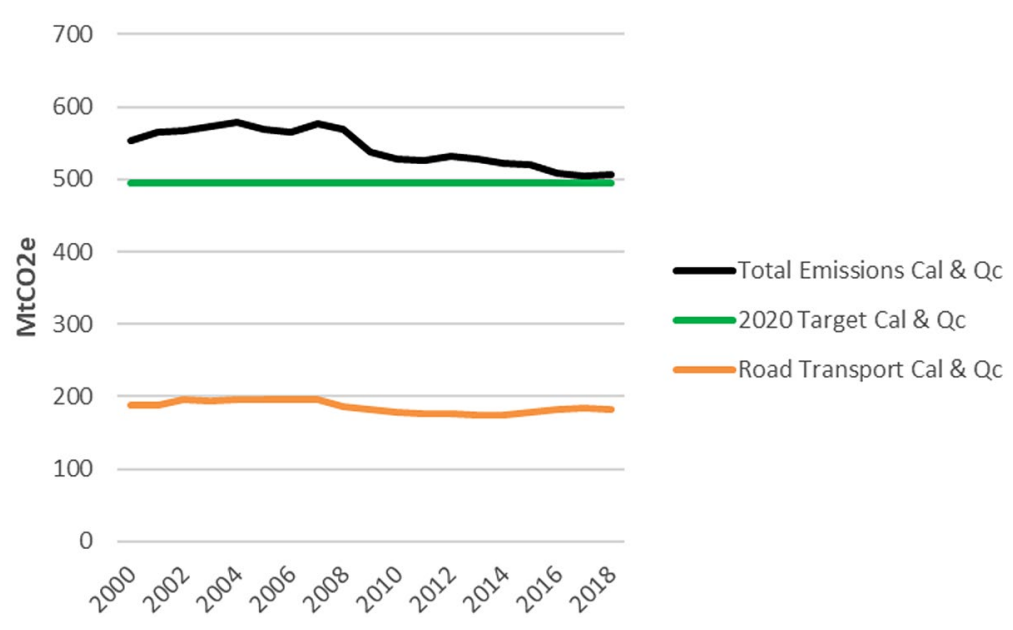

F I G URE 2 Total emissions and emissions in the road transport sector in California and Quebec, $2000-2018$. Source: CARB (2020a), MELCC (2020b)

financial crisis, total emissions between the two jurisdictions were, by 2018, just $12 \mathrm{MtCO} 2 \mathrm{e}$ (million tonnes carbon dioxide equivalent) shy of their collective 2020 emission reduction target of $494 \mathrm{MtCO}$ e. California actually surpassed its 2020 emission reduction target in 2016 (CARB, 2020a), while by 2018 Quebec had reduced emissions on its territory 6.0\% below 1990 levels (MELCC, 2020b). However, as suggested earlier, because Quebec had taken on a much stronger 2020 emission reduction target than California, Quebec was still approximately 13 MtCO2e shy of its target. These trends reflect aggregate changes in each jurisdiction's emission inventories and do not report inter-jurisdictional emissions trading.

As seen in Figure 3, primary and secondary market prices have generally hugged the floor, which was introduced to ensure a minimum price for auctioned allowances and mitigate the potential impact of an oversupply of emission allowances (discussed further below). In February 2021, the primary market price stood a little above the price floor, at \$17.80 USD (CARB \& MELCC, 2021), while prices on the secondary market reached $\$ 18.70$ USD in April 2021. Secondary market prices dropped to approximately $\$ 13.00$ USD during the worst of the covid-19 pandemic in March and April 2020 before recovering to just above the price floor in May 2020. What will future market prices be? We return to that question below after discussing econometric modeling of the relationship between cap-and-trade and flexible regulations.

For the moment, we point out that the actual extent of emissions trading between California and Quebec is difficult to determine because current rules stipulate that allowance holdings by each jurisdiction are not to be made available until the close of the 2013-2020 carbon market commitment period. Despite concerns about market transparency (IEMAC, 2018, p. 54), other evidence provides insight. Overall, the evidence indicates that market prices diverge significantly between the two jurisdictions and that there are considerable gains from trade, particularly from Quebec's perspective. Furthermore, as suggested earlier, because California's economy and emissions are much greater, Quebec will be largely a price-taker in its carbon market relationship with California.

More specifically, previous modeling efforts estimated that on average, over 2013-2020 the Quebec-California market would see Quebec firms purchase between 14.8 to $18.3 \mathrm{MtCO} 2 \mathrm{e}$ of emission allowances from California counterparts, costing between $\$ 428$ and $\$ 644$ million USD (CARB, 2012, pp. 84-86, 91-93; WCI Economic Modeling Team, 2012, p. 7). See Figure 4. This would reduce 


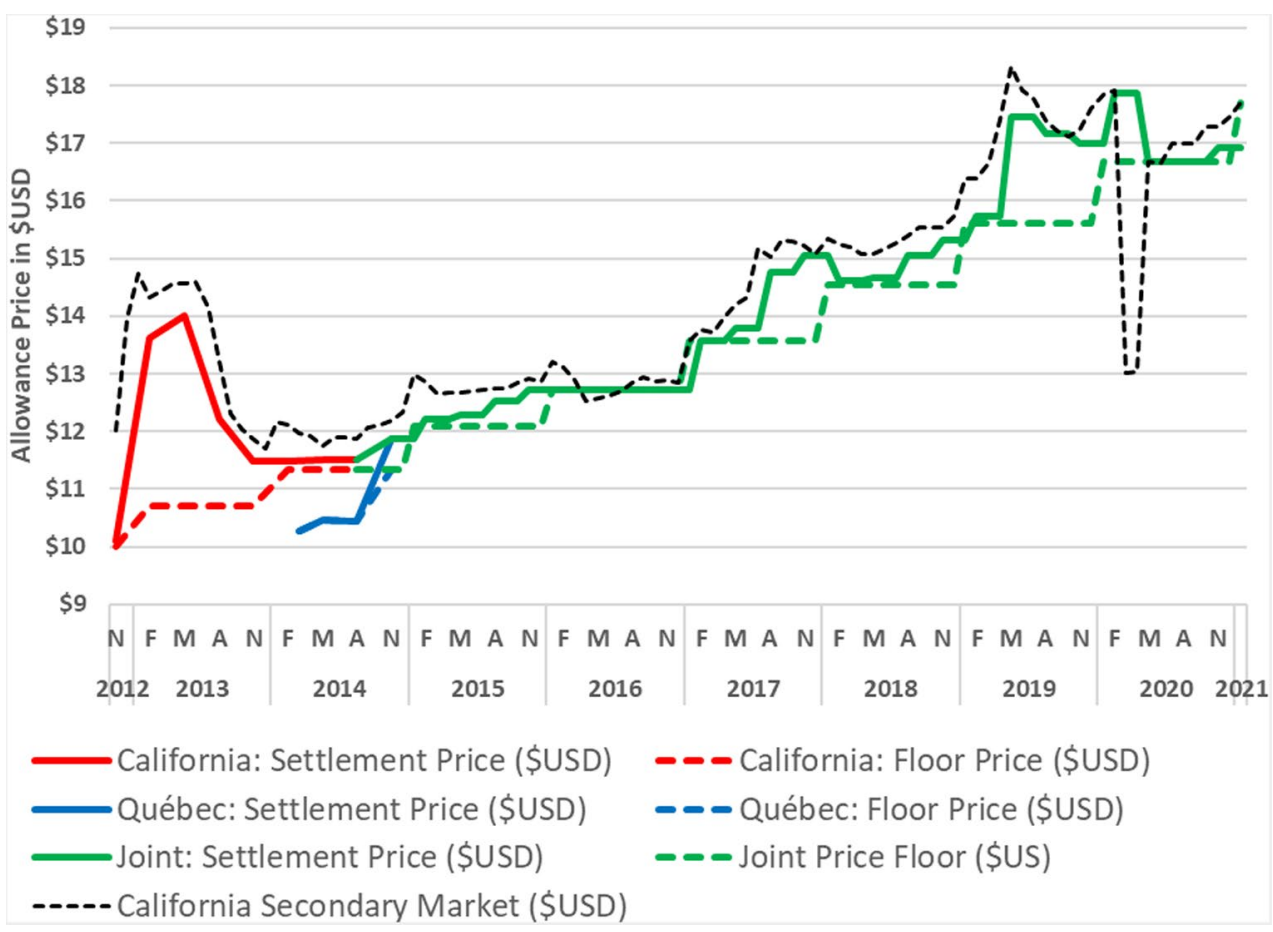

F I G U RE 3 Evolution in allowance price floor as well as primary and secondary market allowance prices, 2012-2021. Source: Data concerning prices floors and primary market prices are derived from quarterly auction reports of CARB and MELCC. Price data for the secondary market comes from "California Carbon Dashboard" (www.calcarbondash.org) for 2012-2017 and "California Carbon Info" (www.californiacarbon.info) for 20182021

Quebec compliance costs by 20\%-52\% compared to the costs of reducing emissions in Quebec alone. For Quebec to reach its 2020 emission reduction goal without linking with California, allowance prices would have been expected to reach \$59-\$69 USD per tCO2e by 2020; in a linked scenario projected prices were expected to rise to \$31-\$55 USD per tCO2e. While ex-ante modeling efforts estimated a slight increase in carbon prices in California due to increased demand from Quebec firms, California would gain \$384-\$634 million USD in emissions trading inflows. That is the result of \$428-\$644 million USD worth of Californian allowances purchased by Quebec firms minus a modest increase in the cost of allowances in California vis-à-vis an unlinked scenario. Nonetheless, despite transfers to California, Quebec would save \$162-\$450 million USD in compliance costs relative to an unlinked market. Looking towards 2030, economic modeling of Quebec's linkage to California suggests similar patterns in emissions trading (MFQ, 2017).

We note that the secondary market prices observed on the California-Quebec carbon market at \$18.70 USD per tCO2e in April 2021 are well below the 2020 prices estimated through ex-ante modeling and summarized in Figure 3. Lower-than-anticipated carbon market prices have raised concerns about the ability of the carbon market to decarbonize California and Quebec's economies. The total cost of reaching California's 2030 climate goal has been estimated at $\$ 80$ USD per tCO2e and between \$124 and \$190 per tCO2e for the state's 2050 goals (Yang et al., 2015, 2017). Similarly, technological changes in Quebec to drive significant emission reductions to reach just the province's 2030 target are expected to occur only at prices above \$79 USD (\$100 CDN) per tCO2e (MFQ, 2017, p. 38). 


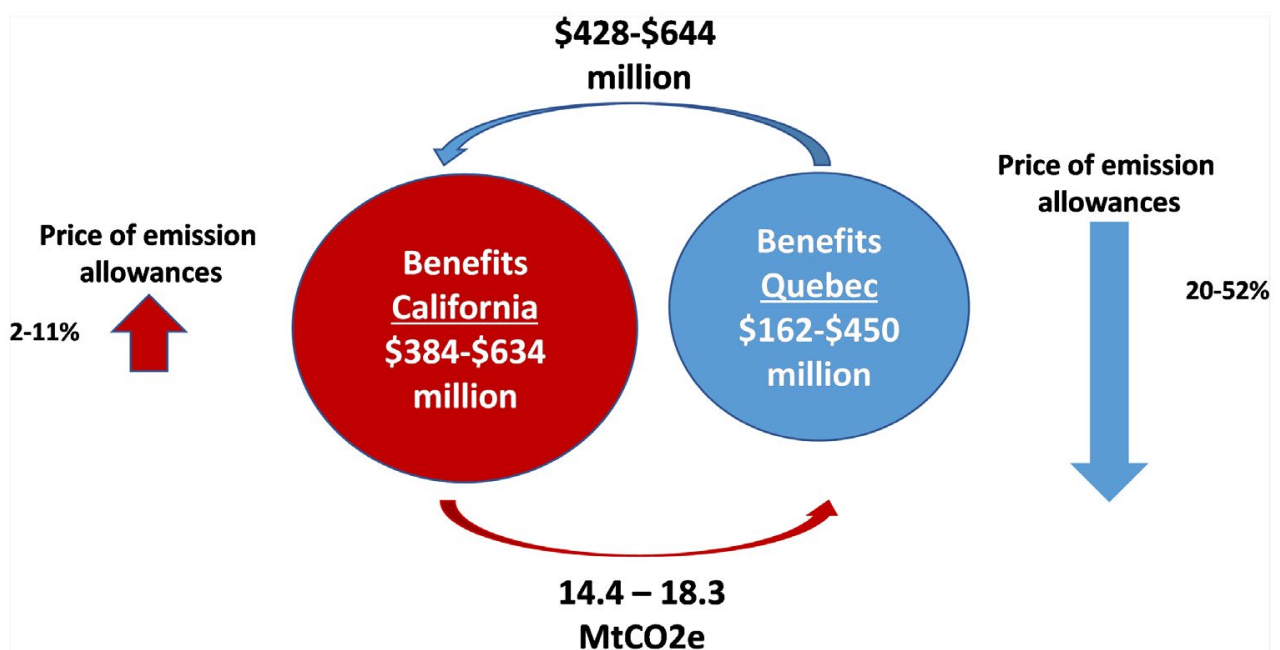

\begin{tabular}{|l|c|c|c|}
\hline & $\begin{array}{c}\text { Prices California } \\
\text { Unlinked } \\
\mathbf{\$} \text { tcO2e }\end{array}$ & $\begin{array}{c}\text { Prices Quebec } \\
\text { Unlinked } \\
\mathbf{\$} / \text { tCO2e }\end{array}$ & $\begin{array}{c}\text { Prices Cal-Qc } \\
\text { Linked } \\
\mathbf{\$} / \text { tcO2e }\end{array}$ \\
\hline Price 2013 & $\$ 15-34$ & $\$ 37-43$ & $\$ 16-35$ \\
\hline Price 2020 & $\$ 27-54$ & $\$ 59-69$ & $\$ 31-55$ \\
\hline
\end{tabular}

F I G U R E 4 Expected carbon prices and benefits of emissions trading between California and Quebec over the period 2013-2020 relative to an unlinked scenario. Source: Adapted from Purdon and Sinclair-Desgagné (2015, p. 13) which was based on CARB (2012, pp. 84-86, 91-93) and WCI Economic Modeling Team (2012, p. 7)

Low carbon prices can be explained by structural oversupply: more allowances have been issued for the carbon market than are required by firms, dampening carbon prices (Borenstein \& Bushnell, 2018; Busch, 2017; Cullenward \& Coghlan, 2016; IEMAC, 2018). The source of oversupply is multifaceted. It can be attributed in part to miscalibration of emission quotas required, unexpected emissions reductions from the 2008 financial crisis and a more rapid transition to renewable electricity than projected. While rules addressing oversupply have been tightened (Schatzki \& Stavins, 2018b, pp. 18-19), more might still be done to address oversupply allowances held in private accounts. Additionally, oversupply might be the result of rules governing electricity imports and associated emissions, which are associated with concerns about emissions leakage via resource shuffling (Cullenward, 2014; Cullenward \& Coghlan, 2016).

While concerns about miscalibration and resource shuffling deserve further investigation, other factors also contribute to low prices-of salience here, the relationship between carbon pricing and flexible regulations.

\section{Modeling the relationship between cap-and-trade and flexible regulations in California}

Recent research by Borenstein et al. $(2017,2018,2019)$ suggests that low carbon market prices result from structural characteristics that make it much more likely for prices to attain either at 
the price floor or price ceiling rather than within its working range. The research of Borenstein and colleagues is unique in attempting to empirically model both carbon pricing and the impact of flexible regulations on carbon pricing, with separate modeling efforts for the initial 2013-2020 period as well as for 2021-2030. We note that their analysis assumes flexible regulations hitting regulatory targets rather than directly modeling them. It also assumes investments in clean technology have limited effect lowering the cost of future emission reductions. Nonetheless, their research is one of the most comprehensive investigations of California carbon market behavior and, hence, has implications for Quebec and other jurisdictions interested in linking.

The key main findings emanating from this research are estimates of the probability of the carbon market price settling at either the administratively determined price floor and ceiling or between the two. As summarized in Table 2, they estimated that over 2013-2020 there was a 94\% probability of market prices remaining near the price floor under California's full suite of climate policies (characterized by complementary policies and market prices free to range from about $\$ 15$ to $\$ 60$ USD per tCO2e). This probability reduces to $46 \%$ and $45 \%$ for the period $2021-2030$ for two scenarios that both include complementary policies, respectively, one with an initial carbon ceiling set at \$58 USD and another set at \$78 USD (Table 2). Recall that the initial price ceiling for 2021 has been officially set at \$65 USD, increasing annually at 5\% plus the rate of inflation.

Three interrelated factors drive low carbon prices on the California carbon market according to this line of research. First is the extremely high level of uncertainty about the amount of emission reductions necessary for California to meet its economy-wide emission reduction targets. This is due to uncertainty associated with California's business-as-usual emissions as well as what reductions flexible regulations can achieve. Uncertainty about the amount of emission reductions necessary to meet the cap frustrates the ability of carbon market prices to equilibrate to the level of abatement required.

Second, the price responsiveness of emission reductions to expected carbon prices is low relative to uncertainty about the amount of abatement required. Under these conditions, flexible

TABLE 2 Summary of allowance price probabilities

\begin{tabular}{|c|c|c|c|}
\hline & $\begin{array}{l}\% \text { Probability price } \\
\text { at floor }\end{array}$ & $\begin{array}{l}\% \text { Probably price at } \\
\text { interior equilibrium }\end{array}$ & $\begin{array}{l}\% \text { Probability } \\
\text { price at ceiling }\end{array}$ \\
\hline \multicolumn{4}{|l|}{$2013-2020$} \\
\hline with complementary policies & $94.3 \%$ & $1.1 \%$ & $4.6 \%$ \\
\hline \multicolumn{4}{|l|}{$\begin{array}{l}\text { prices from } \$ 15 \text { (floor) to } \$ 60 \\
\quad \text { (ceiling) }\end{array}$} \\
\hline without complementary policies & $83.1 \%$ & $6.2 \%$ & $10.7 \%$ \\
\hline \multicolumn{4}{|l|}{$\begin{array}{l}\text { prices from } \$ 15 \text { (floor) to } \$ 60 \\
\quad \text { (ceiling) }\end{array}$} \\
\hline \multicolumn{4}{|l|}{$2021-2030$} \\
\hline with complementary policies & $46.2 \%$ & $19.9 \%$ & $33.9 \%$ \\
\hline \multicolumn{4}{|l|}{$\begin{array}{l}2021 \text { prices from } \$ 18 \text { (floor) to } \$ 58 \\
\text { (ceiling) }\end{array}$} \\
\hline with complementary policies & $45.0 \%$ & $14.5 \%$ & $40.5 \%$ \\
\hline $\begin{array}{l}2021 \text { prices from } \$ 18 \text { (floor) to } \$ 78 \\
\text { (ceiling) }\end{array}$ & & & \\
\hline
\end{tabular}

Source: Borenstein et al. (2017, pp. 8-9, 12, 2019, pp. 3955, 3972, 3974). 
regulations play a larger role by driving emission reductions at higher implicit cost. For example, Borenstein et al. (2018) estimated that emission trading would result in between 18 to $53 \mathrm{MtCO} 2 \mathrm{e}$ of reductions across sectors at carbon floor and ceiling prices, respectively, over 2013-2020 (Table 3). However, assuming flexible regulations meet their targets, emissions would be reduced by a total of $141 \mathrm{MtCO} 2 \mathrm{e}$. This is because California's flexible regulations offered abatement at costs higher than carbon market prices during 2013-2020. A similar estimate of emission reductions driven by carbon pricing and regulations for the 2021-2030 period is not available in Borenstein et al. (2017, 2019).

This brings us to the third cause of low carbon market prices in California: political feasibility. The study of Borenstein et al. (2019) was limited to "the range of GHG prices generally deemed politically acceptable" (p. 3954) — that is, those between the price floor and price ceiling as set by California's policy-makers. Recall that carbon prices modeled for 2013-2020 range from about $\$ 15$ to $\$ 60$ USD per tCO2e while for 2021-2030 the initial prices range from $\$ 18$ to $\$ 58 / \$ 78$ USD per tCO2e (rising to approximately $\$ 27$ and $\$ 90 / \$ 121$ per tCO2e by 2030 ), depending on the price ceiling considered.

The relative gain in efficiency from moving from the current combination of carbon market and flexible regulations to market alone is modest. While removing complementary policies would have increased the probability of market prices settling between the price floor and ceiling, the increase would be only from $1.1 \%$ to $6.2 \%$ during the $2013-2020$ period (Table 2). Looking ahead to 2030, the probability of reaching an interior equilibrium price in the presence of flexible regulations is somewhat higher, at $15 \%-20 \%$ for the two price ceiling scenarios (the researchers do not consider a 2021-2030 scenario without complementary policies).

Returning to our earlier question about future carbon prices on the California-Quebec carbon market, the few techno-economic models looking out to 2030 do not anticipate prices approaching the official 2030 price ceiling of \$101 USD. One modeling effort of California's carbon market considered four different scenarios for achieving the state's 2030 emission reduction target (Yang

T A B L E 3 Emission reductions via carbon market allowance pricing, flexible regulations, and other nonprice factors over 2013-2020

Average modeled reductions over 2013-2020

\section{Source of abatement supply}

Price floor MtCO2e Price ceiling MtCO2e

Emission reductions response to allowance prices

$\begin{array}{lrr}\text { Electricity } & 3.4 & 9.7 \\ \text { Transport } & 3.6 & 12.2 \\ \text { Natural gas } & 11.2 & 31.6 \\ \text { Emission reductions resulting from flexible regulations } & & 77.9 \\ \text { Vehicle emission standards \& LCFS } & 77.9 & 63.1 \\ \text { Renewable portfolio standard \& other policies } & 63.1 & \\ \text { Emission reductions resulting from other non-price factors } & & 9.6 \\ \text { Exogenous electricity rate effects } & 9.6 & 63.2 \\ \text { Electricity imports } & 63.2 & 97.8 \\ \text { Offsets } & 97.8 & 365.0 \\ \text { Total } & 329.7 & \end{array}$

Source: Borenstein et al. (2019, pp. 3966, A20-A31). 
et al., 2017). The highest price determined through modeling was $\$ 80$ USD per tCO2e, which was associated with a scenario where complementary policies play only a limited role; a scenario reflecting California's current policy suite obtained a price of \$56 per tCO2e. The implication is that market prices are unlikely to rise to levels sufficient on their own to achieve neither California's nor Quebec's 2030 emission reduction targets.

\section{COMPARING FLEXIBLE LOW-CARBON TRANSPORT REGULATIONS IN CALIFORNIA AND QUEBEC}

Below we discuss the evolution of flexible regulations in the transportation sectors of California and Quebec, making references to US and Canadian federal governments as appropriate. We organize the presentation of these results according to vehicle fleet decarbonization (vehicle emission standards and ZEV mandates), transport fuel decarbonization (fuel carbon intensity standards) as well as transportation demand management. See Table 4 for a timeline of the transport policy instruments involved as well as carbon pricing.

\section{Vehicle fleet decarbonization: Vehicle emission standards}

\section{California vehicle emission standards}

California's early efforts to address air quality led to the development of significant policy capacity in this area before the US federal government, which granted California a conditional exemption to pursue stricter vehicle emission standards (Fern, 1997; Peesapati, 2018; Rabe, 2018). The US federal government had established the corporate average fuel economy (CAFE) standards for passenger cars in 1975, under the authority of the National Highway Traffic Safety Administration, NHTSA (Oster, 2019).

The low-emission vehicles (LEV) program was first introduced in 1990 to address criteria pollutant exhaust emissions (Hanemann, 2007). By the 2000s, California added GHG reductions to its goal of air quality, beginning in 2002 with passage of the California Clean Cars (CCC) Law, referred to as the Pavley Law. California's first bill to designate $\mathrm{CO} 2$ as a pollutant (CARB, 2017c), the Pavley Law directed CARB to adopt the maximum feasible and cost-effective vehicle emission standards beginning with the 2009-2016 vehicle model years (CARB, 2004). For a time, the Pavley Law was caught in legal incertitude. In 2007, the Bush Administration denied an EPA waiver for California - a first for the EPA - and adopted less-rigorous federal standards under amendments to the Energy Independence and Security Act, EISA (Berck et al., 2010, pp. 5052). However, the subsequent Obama administration granted a waiver in 2009 and established a harmonized National Program involving NHTSA, EPA and CARB for regulating fuel efficiency standards, allowing California to move ahead with implementation (Oster, 2019).

In 2012, the California government adopted additional vehicle emission standards for vehicle model years 2017-2025 under the National Program and introduced the Advanced Clean Cars (ACC) program, also known as Pavley II. This program included updated LEV regulations in order to reduce criteria pollutants and GHG emissions from light- and medium-duty vehicles and has been expected to reduce GHG emissions by 40\% relative to 2012 model years (CARB, 2017b, 2018b). 


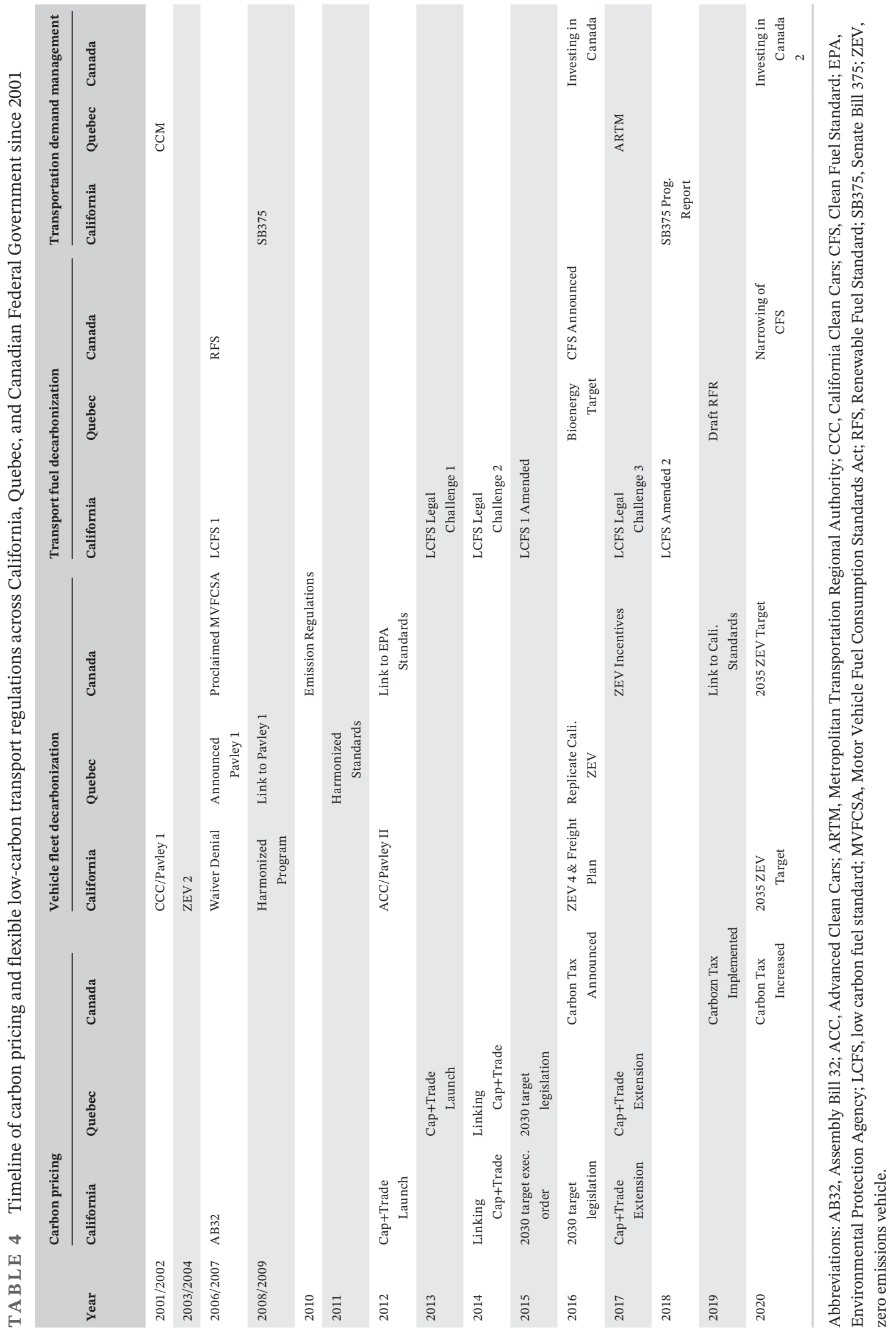


Vehicle emission standards in Canada and Quebec

Vehicle emission standards in Canada have historically been characterized by considerable effort to harmonize with those of the US auto market. The Canadian federal government's efforts towards integration began with the 1965 Canada-US Auto Pact, which has been superseded by subsequent free-trade agreements (CAA \& Pollution Probe, 2009; Carrillo, 2004; TransportPolicy. Net, 2018).

In 1976, the Canadian federal government also established Company Average Fuel Consumption (CAFC) targets and harmonized them with the just released CAFE standards in the US. However, CAFC targets were not made mandatory, despite passage of the Motor Vehicle Fuel Consumption Standards Act (MVFCSA) in 1982. Because US auto manufacturers with operations in Canada were already striving to meet US federal CAFE standards, they agreed to meet the Canadian CAFC standards voluntarily.

Under a new center-right Conservative party leadership, the Canadian federal government began to shift towards mandatory fuel economy standards in 2007, the same year that the Bush administration had denied Pavley I. That year the Canadian federal government finally proclaimed the 1982 MVFCSA, effectively making its CAFC standards mandatory. However, these also reflected the more diluted US federal vehicle emission standards of the Bush era. As observed by Aklin and Mildenberger (2020), this reflected the Harper government's expressed position that Canadian climate policy should not surpass US efforts.

Quebec, however, took action to accelerate the adoption of more stringent vehicle emission standards of California. In its 2006 Climate Change Action Plan, the Quebec government announced that it would adopt California's Pavley Law (MDDELCC, 2008, pp. 25-26). In 2009, the Regulation Respecting Greenhouse Gas Emissions from Motor Vehicles was adopted by the Quebec government and came into force in early 2010 (CCA-Quebec, 2008). The Canadian federal government replaced the CAFC in 2010 with the Passenger Automobile and Light Truck Greenhouse Gas Emission Regulations for vehicle model years 2011-2016. Significantly, these were aligned with new federal vehicle emission standards under the National Program of the Obama administration. Consistent with the Harper government's commitment to alignment with US policy, it is perhaps the most important contribution to climate policy under his tenure. Consequently, in 2011, Quebec officially amended its vehicle emission standards to harmonize with new, more stringent Obama-era vehicle emission standards of the US and Canadian federal governments (MELCC, 2019). Furthermore, regulations officially linking Canadian federal emission standards to US federal standards were introduced in 2012 for model years 2017-2025 (Posada et al., 2018). However, given the Trump administration's intention to freeze vehicle emission levels, the Canadian federal government, under new center-left leadership following 2015 elections, delinked from US federal standards in 2019 and aligned with California's vehicle emission standards (Boyd \& Rabe, 2019; Weikle, 2019).

\section{Vehicle fleet decarbonization: ZEV mandates}

\section{California's ZEV mandate}

California included a ZEV mandate in its 1990 LEV regulations, as ZEVs were initially viewed from the perspective of air quality (Collantes \& Sperling, 2008). The ZEV mandate initially required a minimum share of new car sales to be ZEV: $2 \%$ in 1998, 5\% in 2001, and 10\% in 2003 
(CARB, 1998). It also had features to provide flexibility to automobile makers through a ZEV crediting system (CARB, 2018d). As observed by Stokes and Breetz (2018), the initial California ZEV mandate proved too ambitious and had to be expanded to include both ZEVs and partial ZEVs given insufficient battery technology and high costs. Nonetheless, the initial phase of California's ZEV mandate (1990-2003) proved an effective technology forcing policy instrument. At the beginning of the mandate, there were only $2300 \mathrm{ZEV}$ credit applicable vehicles on the road in California while this number reached 140,000 by 2003 (CARB, 2000, 2003). A legal challenge resulted in a temporary injunction and a subsequent revised ZEV mandate for 2004-2011 included greater sophistication to reflect diversified types of vehicles (CARB, 2020b; Wesseling et al., 2014).

California's ZEV mandate was updated in 2012 under California's ACC program. A ZEV credit percentage requirement of $4.5 \%$ in 2018 and $22 \%$ for 2025 was adopted with a view toward meeting a 2030 ZEV deployment target of 5 million (CARB, 2016; Next 10, 2018). In 2016, the ZEV mandate was expanded to the truck fleet through the California Sustainable Freight Action Plan (CALTRANS, 2016). While not a flexible regulation, an executive order was signed in 2020 by Governor Newsom requiring that all new passenger vehicles in California be ZEVs by 2035 (Grandoni et al., 2020).

\section{ZEV mandates in Quebec and Canada}

The Quebec government introduced a ZEV mandate in 2016, which came into force in 2018 (Government of Quebec, 2018). The policy makes explicit reference to California's (MELCC, 2019). Between 2018 and 2025, the share of ZEVs is expected to increase from approximately 3\% to $20 \%$ of total vehicle sales (Whitmore \& Pineau, 2018) - just slightly below ZEV requirements in California discussed above. Replicating California, Quebec announced in late 2020 a similar measure limiting new vehicle sales to ZEVs by 2035 (CBC, 2020)_though we note that in 2019 British Columbia passed legislation targeting a similar outcome by 2040 (Statt, 2019).

At the federal level, Transport Canada also announced in 2017 its intention to adopt a ZEV mandate by the end of 2018 (Transport Canada, 2017). However, this federal measure was still pending in 2021 (Brazeau, 2021). The Canadian federal government has set ZEV sales targets of $10 \%$ by $2025,30 \%$ by 2030 , and $100 \%$ by 2040 though, by its own assessment, ZEVs are only expected to constitute $5 \%-10 \%$ of all new light-duty vehicles purchased by 2030 (Clean Energy Canada, 2020).

\section{Transport fuel decarbonization: Fuel carbon intensity standards}

\section{California's LCFS}

An executive order issued by Governor Schwarzenegger in 2007 established the LCFS, which was first implemented in 2011 (Kahn, 2007; Yeh et al., 2016). The standard operates by setting a benchmark for carbon intensity (CI, the amount of carbon dioxide equivalent per megajoule of energy) of transportation fuels in the state, then gradually reducing that benchmark over time. Critically, CI ratings consider the full life cycle of the fuel, from production to combustion. Relative to 2010 benchmark levels, the LCFS requires vehicle fuel producers and distributors to reduce the carbon intensity of transport fuels by $10 \%$ by 2022 and by $20 \%$ by 2030 (CARB, 2019c). 
Modeling is essential to California's LCFS. It provides information for estimating transport fuel CI through a complex life-cycle assessment-including emissions associated with indirect landuse change (Breetz, 2017; Farrell et al., 2007).

The LCFS also introduced a credit system to promote flexibility. While firms accumulate market deficits from the production and sale of liquid fossil fuels, these can be balanced by acquisition of credits generated from activities that promote low-carbon fuels such as biofuels, low-carbon electricity as well as ZEV charging infrastructure. Biofuel production and importation continues to be the most important crediting generation activity for the California LCFS (CARB, 2021). Low-carbon fuel generates a credit, measured in $\mathrm{tCO} 2 \mathrm{e}$, for emissions savings relative to the annual standard based on the fuel's CI rating. When first introduced in 2013, credits were trading at under $\$ 20$ USD per tCO2e, rose to $\$ 80$ by the end of the year and reached about $\$ 200$ USD per tCO2e in 2020 (Duffy, 2019; Yeh et al., 2016, p. 228). While both the carbon market and LCFS use credits denominated in tCO2e, we stress that the two represent different measures that are neither directly interchangeable nor representative of the same effect on total GHG emissions.

The flow of fuels with low CI ratings into California has increased under the program. Over 2011-2017, the contribution of alternative low-carbon fuels grew from $6.2 \%$ of California's transportation fuels to $8.5 \%$ while their average CI rating in the program declined 36\%; by the program's internal calculations this corresponded to estimated emissions reductions of $38.3 \mathrm{MtCO} \mathrm{e}$ from 2010 levels (Witcover, 2018). Liquid biofuel production continues to generate the majority $(\sim 80 \%)$ of LCFS credits though electricity has risen to represent $19 \%$ of total credits in 2020 (CARB, 2021).

\section{Fuel carbon intensity standards in Quebec and Canada}

While Quebec has no explicit transport fuel carbon intensity standard, since 2016 several Canadian federal agencies have been developing a low-carbon fuel standard similar to California's known as the Clean Fuel Standard (ECCC, 2017, 2019a). The Canadian federal CFS initially aimed to not only reduce fossil fuel use in the transportation sector, like California, but also that of industry, homes and buildings. Under the new Canadian federal climate strategy, the scope of the CFS has been limited to only liquid fuels (ECCC, 2020, p. 27). The life-cycle assessment model and related components are expected to come into force in late 2022 (Government of Canada, 2020).

The Canadian province of British Columbia implemented a LCFS shortly after California, sharing many properties of the California policy but not indirect land use change in its lifecycle analysis (Yeh et al., 2016, p. 229). The blueprint for Canada's CFS likewise includes no indirect land use change component in its life-cycle assessment model and proposes instead to establish land-use and biodiversity (LUB) criteria, which would apply to feedstock regardless of geographic origin.

While Quebec offered a tax credit to biofuel producers as early as 1996, until recently it deferred to the Canadian federal Renewable Fuel Standard (RFS) established in 2006, which set blend mandates at 5\% gasoline and 2\% diesel (Bradford, 2019; Steenblik, 2007). It was not until 2016 that Quebec adopted the 2030 Energy Policy, which committed to a 50\% increase in bioenergy production relative to 2013 levels (MERN, 2016). But an instrument for achieving this goal was not developed until 2019, when the Quebec government tabled a draft Renewable Fuels Regulation (RFR) that would see these rise to $15 \%$ and $4 \%$ by 2025 for gasoline and diesel, respectively (Gouvernement du Québec, 2019). However, other Canadian provinces have been much more proactive in advancing biofuel production. Saskatchewan and Manitoba enacted gasoline 
blending policies higher than the federal level as early as 2010; BC and Ontario have maintained a diesel blending mandate above the federal levels since 2010 and 2016, respectively (Wolinetz et al., 2019).

\section{Climate policy and regional transportation demand management}

\section{Regional climate and transportation planning in California}

Here, we shift from jurisdiction-wide policies focused on vehicle fleet and transportation fuel decarbonization to transportation demand management at the regional/municipal level. The Sustainable Communities and Climate Protection Act of 2008 (Senate Bill 375, "SB375") is a pioneering policy tool that requires metropolitan regions in California to tackle regional vehiclerelated GHG emission by building on the regional transportation planning system in the US (Barbour, 2020).

Since 1962, any US metropolitan area with a population of greater than 50,000 must create a metropolitan planning organization (MPO) to facilitate a "continuing, comprehensive, and cooperative" transportation planning process in order to obtain federal transportation funds (Sciara, 2017). MPOs fulfill this mandate by creating regional transportation plans (RTPs) every five years, which define transportation investments over the next twenty years (Sciara \& Handy, 2017). With the passage of the federal Intermodal Surface Transportation Efficiency Act (ISTEA) in 1991, transportation planning was linked with air quality planning. Any metro area out of attainment with federal air pollution criteria had to develop a transportation plan that helped reduce air pollutant emissions to acceptable levels (CARB, 2017e; Sciara, 2017). The next logical step was an extension to climate change objectives, which is where the California government has asserted itself with SB375.

There are two key elements of SB375 for integrating climate policy into the regional planning process in California. First, SB375 required that MPOs adopt "Regional Plan Climate Targets" expressed as a percent change in per capita passenger vehicle GHG emissions relative to 2005 (CARB, 2018c). In practice, these focus on reductions in vehicle miles traveled (VMT). Across California, 18 MPOs currently plan, on average, a 9.6\% reduction in per capita passenger vehicle GHG emissions by 2020 relative to 2005 levels and an 18\% reduction by 2035 (CARB, 2018a, pp. 22-23).

Second, SB375 required that a Sustainable Communities Strategy (SCS) be incorporated into the RTP. The SCS requires: (i) a land use element that accommodates forecasted population growth and (ii) a transportation network to meet all regional needs (ILG, 2015). In effect, the SCS requires that MPOs identify strategies to reduce GHGs emissions from vehicles (CARB, 2019b). Some flexibility is offered in that, if a region is unable to meet its original SCS reduction targets, it has the option of preparing an Alternative Planning Strategy (CARB, 2019b). Importantly, under SB375, CARB determines SCS compliance, giving the state agency a new direct role in the RTP process.

A 2018 progress report on SB375 indicated that GHG emission reduction and VMT targets were not expected to be met in any Californian MPO (CARB, 2018a, Appendix A, A2-A4). This is not unexpected as it is generally recognized that public transport investments alone have weak impact on GHG emissions (Carroll et al., 2019; Rodier, 2009). But CARB and MPOs also struggle with regional data on VMT and GHG emissions necessary for evaluating SB375 (CARB, 2018a, pp. 23-24), although CARB has not yet imposed penalties for non-compliance (Barbour, 2020; 
CARB, 2019b). The reasons for underperformance are a matter of open discussion-see Barbour (2020) for the latest—but underscore the challenge with transportation demand management.

\section{Regional climate and transportation planning in Quebec}

No institution has been created by the Canadian federal or Quebec provincial governments comparable to MPOs in the American context. As a result, unlike California, no municipality within Quebec nor Canada requires transport modeling to demonstrate policy conformity with stated plans to reduce transportation emissions. This is exemplified by the state of transport planning in the greater metropolitan region of Montreal-the largest in Quebec.

Montreal's 2013-2020 Citywide GHG Emissions Reduction Plan set a municipal emission reduction target of 30\% below 1990 levels by 2020 (Ville de Montréal, 2018). While the city's efforts have so far led to emission reductions of $28 \%$ below 1990 levels, most of the emission reductions were from fixed sources while those from transportation slightly increased (Ville de Montréal, 2019 , pp. 6-7). This is attributed to the growth of vehicle use and a decrease in public transit use (Ville de Montréal, 2018). Such patterns have likely been exacerbated over 2020-2021 due to the covid pandemic.

Looking to the wider Montreal region, two organizations share some of the characteristics with MPOs in the US. All municipalities are represented under the authority of the Communauté métropolitaine de Montréal (CMM), created in 2001. It has authority in the planning, coordination and funding of land use, public transit, economic development, social housing and environment (CMM, 2019). A new body to administer and coordinate public transport was introduced in 2017, known as the Metropolitan Transportation Regional Authority (ARTM). The City of Montreal has its own public transportation service, but its coordination with other transport services in the larger metropolitan area is now governed by ARTM. In contrast to MPOs in the US, neither the CMM nor ARTM have regional emission reduction targets nor use transportation forecasting models for monitoring compliance with existing air quality standards.

The situation in the Montreal region contrasts to a certain degree with new transport infrastructure programs of the Canadian federal government. In 2016, Infrastructure Canada's committed \$29 CDN billion ( $\$ 22$ USD billion) and \$27 CDN billion ( $\$ 20$ USD billion), respectively, to public transit and green infrastructure through the Investing in Canada Plan (Infrastucture Canada, 2018, 2019b). The allocation of funds to provinces and municipalities for green infrastructure is undertaken through the Climate Lens programme (Infrastucture Canada, 2019a), requiring emissions from new federally funded infrastructure projects be calculated using methodologies similar to offsetting. The recent Canadian federal climate strategy intends on building on the Investing in Canada Plan, securing permanent public transit funding, investing in electrification of public transit and the development of a national active transportation strategy (ECCC, 2020, p. 17). However, none of these programs anticipate a comprehensive and flexible planning tool for low-carbon transportation as observed in California.

\section{DISCUSSION}

We frame our discussion in terms of an analytical framework delineating different political logics along the clean technology experience curve introduced earlier. The extensive use of regulations in California and Quebec suggest that, during the initial phase of emissions trading from 
2013-2020, both jurisdictions have been at the middle level of the clean technology experience curve for transportation while Quebec has arguably already reached the bottom of the curve in terms of clean energy. At these levels, emission trading largely functions to generate revenue in support of the low-carbon transition though it has also served as a safety valve for Quebec, offering a pathway for achieving its ambitious 2020 emission reduction target at lower cost. Emissions trading between the two jurisdictions during this initial period has significantly reduced the price of emissions allowances for Quebec firms relative to an unlinked scenario. But we have also seen that flexible regulations have contributed significantly to low carbon market prices during this initial phase.

We have also demonstrated that in addition to the carbon market linkage, Quebec has also consistently replicated many—-though not all—of California's flexible regulations in the transportation sector during this initial period. While Quebec's ZEV mandate is most clearly influenced by California, we have also seen the province align with California's vehicle emission standards as early as 2006 - though the Quebec government would later defer to the Canadian federal standards when these efforts ramped up to California standards. Looking forward to 2030, California and Quebec appear poised to attempt to push through to the bottom of the experience curve with both types of policy instruments-emissions trading and flexible regulations. However, based on the balance of evidence, regulations are likely to continue to deliver the majority of California and Quebec's emission reductions moving forward. While there is a greater probability that carbon market prices will diverge from the price floor over the period 2021-2030, there is still a nearly $50 \%$ chance that they will remain there. We conclude that carbon pricing will not prevail over flexible regulations in California and Quebec's efforts to reduce emissions and decarbonize their transportation sectors, at least not through 2030.

Such findings contribute to theoretical debates about the interaction between carbon pricing and low-carbon regulations by raising a number of specific research questions and hypotheses, which provide the basis for in-depth studies involving a larger universe of cases. These are summarized in Table 5 and explored in more detail in the sections below.

\section{Political economy of policy sequencing in the transportation sector}

First, we hypothesize that flexible regulations continue to be adopted by governments of California and Quebec because they convey considerable political economy benefits in terms of reducing visible costs and distributing them differently than carbon pricing even as both jurisdictions move from the middle towards bottom of the experience curve for clean transportation.

More stringent vehicle emission standards and ZEV mandates confer political economy benefits in two ways. First, the actual costs of the standards on consumers are indirect, conveyed through vehicle sticker prices and generally low enough to be repaid by fuel savings. They are also not particularly salient: consumers are often unable to differentiate the costs of improved fuel standards from other distinguishing features of vehicles (Allcott \& Knittel, 2019). Second, given its significant share of the US auto market, California's vehicle emissions standards and ZEV mandate oblige auto manufacturers to produce cleaner vehicles for the entire North American market—the famous "California effect" (Vogel, 1995). The upshot is that higher costs of meeting California standards are borne not just by car buyers in California (and other jurisdictions adopting its standards) but distributed across the North American market.

Furthermore, in Quebec, adopting a ZEV mandate carries additional political economy benefits. Replacing oil-even from other Canadian provinces-with hydroelectricity from generating 
TA B L E 5 Research questions and hypotheses for future research

Hypothesis 1: Political Economy of Policy Sequencing in the Transportation Sector

- Flexible regulations convey political economy benefits

Hypothesis 2: Implications for Linked Emissions Trading Systems

- 2a: Replication of flexible regulations may alleviate free-riding concerns with regards to emissions trading

- $2 \mathrm{~b}$ : Adoption of more aggressive regulatory instruments may assist jurisdictions linked via emissions trading to address domestic political challenges

Hypothesis 3: Strategic Policy Capacity

- Policy capacity for both sets of policy instruments might be built in a strategic manner that corresponds to a jurisdiction's specific political and economic context

stations within the province operated by a state-owned enterprise reduces fuel costs for drivers in Quebec and generates additional revenue for the province (Langue \& Hafsi, 2010). A similar logic explains the relative delay in Quebec's efforts to accelerate biofuel production, with blending mandates only recently increased. Given its hydroelectric resources, the vehicle fuel system for electric vehicles in Quebec is already largely decarbonized; the challenge is retrofitting charging infrastructure and the vehicle fleet for electrification.

The LCFS in California and similar efforts to incentivize the production of low-carbon fuels in Canada also convey considerable political advantages vis-à-vis carbon pricing. First, relative to carbon pricing, California's LCFS introduces a higher, more focused price that is applied only towards emissions relative to the standard. In contrast, carbon pricing puts a price on all GHG emissions associated with a fuel (except biogenic carbon). This leads to a second major difference: the LCFS penalizes the production of high-CI fuels while subsidizing low-CI fuels, whereas carbon pricing merely penalizes low-CI fuels less than high-CI ones. This carries some attractive features politically. By creating market incentives for the production of low-carbon fuels and electricity, fuel carbon intensity standards build a constituency for decarbonization.

However, given its existing hydroelectric resources, Quebec already possesses sufficient clean energy to supply its transportation sector. Consequently, we hypothesize that an instrument like the LCFS has attracted less interest in Quebec, given that it is already towards the bottom of the clean technology curve for the sector. Instead, the Quebec government has been willing to allow the Canadian federal government to take the lead with the development of a fuel carbon intensity standard.

In comparison to other low-carbon flexible regulations investigated, efforts to reduce emissions associated with regional transportation demand through SB375 appear to be facing the greatest challenges. We submit that this instrument delivers the least political economy benefits of those considered. Indeed, similar to carbon pricing, SB375 ultimately aims to change individual decision-making by planning transportation and land-use investments that will incentive reductions in per capita vehicle GHG emissions. However, relative to carbon pricing, regional plan climate targets may have certain political advantages. The most important innovation is that they are developed through a planning process that allows stakeholders considerable flexibility in how they plan to achieve reductions while also using rigorous modeling techniques to assess effectiveness. Yet while SB375 does allow MPOs to prepare an Alternative Planning Strategy if the intended approach does perform as intended, the flexibility of the policy instrument is more limited than other flexible regulations considered in this study. While MPOs have important powers over the planning process, they have limited authority with regard to land use and planning decisions that execute SB 375's broad strategic goals, given the important role of local jurisdictions over such matters in the US (Barbour, 2020; Wolf \& Fenwick, 2003). This relative lack 
of flexibility may also explain why CARB has been reluctant to impose severe penalties for poor performance to date. However, in contrast to the situation in Quebec and Canada, SB375 appears to have inserted considerable innovation and accountability into regional transport and land-use planning.

Finally, while flexible regulations in the transportation sector appear attractive given the considerable political economy benefits they might deliver, we hypothesize emissions trading still plays a role in mitigating political barriers and smooth-out policy sequencing at all three levels of the clean technology experience curve. Even at low carbon market prices, emissions trading in California and Quebec has generated considerable revenue, some of which has be allocated to targeted climate change mitigation efforts in the transportation sector. In California, the top three programs funded through the GGRF have been high speed rail (\$3.6 USD billion), low carbon transportation (\$2.1 USD billion), the affordable housing and sustainable communities program (\$2.5 USD billion) and transit and intercity rail capital (\$1.3 USD billion) (CCI, 2021, pp. 11-12). In Quebec, the government anticipates spending $\$ 2.8$ billion USD ( $\$ 3.6$ billion $\mathrm{CDN}$ ) on low-carbon transportation through 2026 under the 2030 Plan for a Green Economy, or 55\% of the total budget envelope (Gouvernement du Québec, 2020a, pp. 27-32). There are of course questions about how effectively such funds are being used, which is emerging as an important area of research.

While the carbon price floor is expected to climb, our findings suggests that the governments of California and Quebec will continue to allow regulations to do most of the heavy lifting as the jurisdictions pursue efforts to reach the bottom of the clean technology experience curve. We have also seen that the stringency of vehicle emission standards, ZEV mandates and fuel intensity standards is likely to continue to rise significantly while California continues with its efforts to improve transportation demand management. Importantly, both jurisdictions have pursued greater regulatory efforts in the transportation sector after the introduction of emissions trading, the stringency of which has increased only gradually and at the same rate since 2013.

\section{Implications for linked emissions trading systems}

Our findings also have implications for the interactions between emissions trading and flexible regulation across jurisdictions characterized by significantly different abatement costs. While our results support one dimension of the argument advanced by Cullenward and Victor (2020), that flexible regulations and industrial policy will play a greater role in decarbonization moving forward, our results also call attention to the asymmetric nature of emissions trading between California and Quebec, which challenges their broader claims.

As noted above, California's flexible regulation drive emission reductions at relatively higher implicit cost than what would have been achieved via a free-ranging carbon price. Put differently, the cost of reducing emission in California is higher than prices reflected on the carbon market. This complicates the economic rationale for linking emission trading systems, since carbon market prices do not represent the full cost of the complex suite of policy instruments deployed to reduce emissions in California. As suggested from our review of actual carbon market prices and prices modeled ex-ante, Quebec is buying emission allowances at prices that are lower than the actual costs of reducing emissions in California. However, we have also seen that Quebec has adopted many similar flexible regulations in its transportation sector, which by driving reductions at above-market costs in Quebec might also be expected to depress allowance prices on Quebec's carbon market. Carbon market prices in Quebec after linkage might also be expected to be lower than the costs of efforts to reduce emissions in the province. 
We hypothesize that the replication of Quebec's replication of California-style flexible regulations in the transportation sector has two beneficial political consequences. First it may alleviate free-riding concerns with regards to emissions trading in the presence of depressed market prices. As Quebec has adopted many transportation regulations that are nearly identical to California's, carbon market prices are also lower than the province's actual costs of its efforts to reduce emissions. This may mitigate concerns in California that Quebec is not doing its fair share to reduce its emissions domestically and is free-riding. However, there is emerging evidence that many jurisdictions are comfortable with asymmetric climate policy, at least when costs remain low (Aklin \& Mildenberger, 2020; Mildenberger, 2019).

Second, the adoption of more aggressive regulatory instruments might help both jurisdictions address domestic political challenges. In particular, the heightened regulatory effort in Quebec ensures that domestic efforts to decarbonize the transportation sector are substantial and thereby reduce capital outflows through emissions trading. Such concerns appear salient in Quebec but have not yet provoked a withdrawal from emissions trading. For example, a 2017 survey of 56 firms in Quebec, including 39 with emission reduction obligations under the carbon market, found that approximately $80 \%$ agreed that the carbon market led to capital outflows; however, the majority of respondents also affirmed that it was important to link the Quebec emissions trading system with those in Canada (90\%), North America (86\%) and internationally (59\%) (Lachapelle et al., 2017, pp. 12, 21-22). We also recall that Quebec initially sought a more accelerated increase of the WCI's carbon price floor, which would also have assured greater reductions in-province if politically feasible.

Overall, gains from trade are significant but muted on the California-Quebec carbon market in part because of the significant role of flexible regulations. Such a combination of regulations and emission trading is likely to be uncommon as jurisdictions would need to converge on a similar suite of regulatory instruments in order to reduce such free-rider concerns and domestic disapproval. This might explain the limited interest amongst other jurisdictions to link emission trading with California and Quebec. In contrast, fourteen states have adopted California's vehicle GHG emission standards while eleven US states have adopted California's ZEV program (CARB, 2019e). And California stands apart with its efforts to integrate climate objectives into transportation demand management. We note however that the state of Washington recently passed, in April 2021, legislation to establish a cap-and-trade system compatible with the California-Quebec carbon market, while also adopting its own version of an LCFS (ICAP, 2021). The twin passage of emissions trading and a key flexible regulation in the transportation sector is consistent with our hypotheses about the political economy preferences of governments.

\section{Strategic policy learning}

Our study also contributes to discussions about policy capacity requirements for a complex suite of policy instruments like in California that is comprised of emissions trading and flexible regulations. While our "least-likely" case study limits generalizations, the different instruments pursued by Quebec lead to the hypothesis that policy capacity for both sets of policy instruments might be built in a strategic manner that corresponds to a jurisdiction's specific political and economic context.

First, the observed sequence of transportation policy instruments in Quebec and Canada provides evidence that Quebec has been able to learn from California. While such an argument has been made before with regard to the institutional infrastructure for emissions trading (Rabe, 
2018), our study suggests it might be extended to transportation policy instruments. Though issues of policy capacity might still remain a constraint on the broader diffusion of such a complex suite of policy instruments, California appears to have enabled diffusion by providing the initial blueprints for sophisticated policy instruments-including their technical underpinning. CARB's efforts to facilitate replication of its policies and provide technical assistance to jurisdictions has also helped spur this blueprint model of policy dissemination.

However, policy capacity appears to have been developed strategically with Quebec pursuing instruments that might harness its considerable hydroelectric advantages towards the decarbonization of its transport sector. The flexible regulations that Quebec appears to have replicated from California include its ZEV mandate but also, previously, the adoption of California's vehicle emission standards in 2006, both of which lend themselves to efforts Quebec has been making to replace fossils fuels with electricity. Yet the Quebec government has largely deferred to the Canadian federal government on biofuel policy as well as the development of a policy instrument akin to California's LCFS. We note that the Canadian province of British Columbia, which might be assumed to have similar levels of policy capacity to Quebec, has also implemented its own LCFS since 2010 (Lepitzki \& Axsen, 2018; Yeh et al., 2016). This suggests that policy capacity does not explain Quebec's muted interest in this policy instrument.

However, California's efforts to reduce regional transportation GHG emissions through a flexible regional planning process backed by rigorous modeling requirements has no direct counterpart in neither Quebec nor Canada-although there are various regional/municipal transportation planning efforts. It remains to be seen whether the lack of such a policy instrument in Quebec is due to a lack of policy capacity or, more likely in our view, the lack of an institutional framework akin to the MPO system in the US.

\section{Alternative hypotheses}

In the sections above, we have offered a number of hypotheses in lieu of firm explanations about the observed sequence emission trading and flexible regulations in the transportation sectors of California and Quebec. This is because of a number of alternative hypotheses that we have not been able to exclude given our simple case-study methodology and focus on policy instruments.

A first alternative hypothesis attributes the continued strong role of transportation regulations not to rational decision-makers but to the historical evolution of California's efforts to GHG emissions from earlier efforts to tackle air pollution due to vehicle pollution. The political science literature has pointed to how many institutional frameworks evolved through endogenous political processes over time (Béland, 2007; Thelen, 2004). While we find that reorientation of vehicle emission standards from atmospheric pollution to GHG emissions might constitute "layering", the ZEV mandate and SB375 are better considered as example of "conversion" as they have both drawn on existing policy instruments but whose core objectives and targeted policy actors have been significantly changed from their antecedents, vehicle emission standards and MPO process, respectively. However, emissions trading and the LCFS appear to be quite new policy instruments, which might be better explained by the political economy benefits these instruments confer on governments.

Similarly, Kingdon's (1984) multiple streams model of the policy process might also explain outcomes observed. It seems reasonable that policy entrepreneurs in both California and Quebec have been more successful in promoting the adoption of regulatory instruments over a substantial increase in carbon pricing. The question would be whether such entrepreneurs emerged 
from within government, as our political economy theory hypothesizes, or amongst non-state and transnational policy entrepreneurs.

Another alternative hypothesis about Quebec and Canada's replication of California-style policy instrument points to California's ability to compel other jurisdictions to follow its initiative (Vogel, 1995, 2018). This suggest that the two governments may have been attracted to Californiastyle climate and transportation policy in order to benefit from association with the one of the world's leading jurisdictions. While plausible, this does not explain why so many other jurisdictions have been slow to adopt emission trading and fuel carbon intensity standards. A fourth and related hypothesis is that preferences for different policy instruments might be attributable not to political leadership but to preferences of members of the bureaucracy. For example, Hochstetler (2020) attributes Brazil's pursuit of wind power instead of solar power to analytical approaches of the Brazilian bureaucracy. While plausible, it is difficult to explain the policy durability of emissions trading in Quebec and California for over a decade nor the apparent strategic selection of policy instruments without these issues entering the strategic decision-making arena.

Research over a broader universe of cases and economic sectors are necessary to evaluate our preferred hypotheses relative to alternatives. We would suggest a focus on states and provinces with abatement costs higher than those in California such as Washington, Oregon and British Columbia. While Washington recently adopted both cap-and-trade and LCFS-like legislation, as mentioned above, Oregon has an LCFS and has expressed interest in the past few years of joining the WCI and linking emissions trading with California and Quebec but have not followed through (Rabe, 2018). As is well known, British Columbia opted for a carbon tax rather than participate in emissions trading under the WCI. But GHG emissions in British Columbia have grown by $6.5 \%$ since the carbon tax was first introduced in 2008 and were $22 \%$ above 1990 levels in 2018 (British Columbia, 2020; also see Pretis, 2019 who focuses only on $\mathrm{CO}_{2}$ emissions).

\section{Comparison with Canadian federal strategy}

In this final section, we contrast the policy mix in California and Quebec with the recently proposed Canadian federal strategy. Under the federal strategy, a revenue-neutral carbon tax would rise to approximately \$134 USD (\$170 CDN) per tCO2e by 2030 (ECCC, 2020, p. 26). The high carbon price suggests it will be the primary tool achieving compliance with Canada's 2030 commitments under the Paris agreement. For example, the recently proposed carbon price corresponds to that resulting from modeling efforts of carbon pricing as the primary emissions abatement policy instrument in Canada (Ecofiscal Commission, 2019; PBO, 2020). The reduced scope of the CFS and absence of ZEV mandate and comprehensive metropolitan regional transportation GHG mitigation strategy is also indicative of this tendency. We anticipate that comparisons between the approach of California and Quebec and that of the Canadian federal government will attract increasing attention moving forward.

\section{CONCLUSION}

In this paper we have investigated the interaction between emissions trading and flexible regulations in the transport sector in California and the only jurisdiction linked to it via emissions trading, the Canadian province of Quebec. We have demonstrated that linking emissions trading systems has been asymmetrical with the change in allowance prices being almost unappreciable 
in California while leading to significant reduction from Quebec's perspective. We have also demonstrated that Quebec has been able to replicate many though not all of California's lowcarbon transportation policy instruments. Finally, we have offered evidence that suggests that regulations will continue to prevail over carbon market prices through 2030. In lieu of a firm explanation of these findings, we have offered hypotheses in terms of the political economy advantages of flexible regulations themselves as well as their combination with emission trading in asymmetrical jurisdictions as well as about the strategic adoption of different types of regulatory instruments available. While our study suggests California and Quebec have balanced emissions trading and regulations, the difficulty in reaching such convergence might explain limited participation in the WCI. Attention, however, to conditions that have allowed both sets of policy instruments to gain traction helps identify conditions for replication elsewhere.

\section{ACKNOWLEDGEMENTS}

This research is part of the Joint Clean Climate Transport Research Partnership, which has been funded by a Partnership Development Grant of the Canadian Social Sciences and Humanities Research Council as well as both the Sustainable Transportation Energy Pathways (STEPS) Program and Policy Institute for Energy, Environment and the Economy at University of California, Davis. We would like to acknowledge the research assistance of Louis-Charles Coderre, Myriam Goulet and Sang-O Kim. We also thank two anonymous reviewers for constructive criticism received.

\section{ENDNOTE}

\footnotetext{
1 Authors' translation.
}

\section{REFERENCES}

Aklin, M., \& Mildenberger, M. (2020). Prisoners of the wrong dilemma: Why distributive conflict, not collective action, characterizes the politics of climate change. Global Environmental Politics, 20, 4-27. https://doi. org/10.1162/glep_a_00578

Allcott, H., \& Knittel, C. (2019). Are consumers poorly informed about fuel economy? Evidence from two experiments. American Economic Journal: Economic Policy, 11, 1-37. https://doi.org/10.1257/pol.20170019

Axsen, J., Plötz, P., \& Wolinetz, M. (2020). Crafting strong, integrated policy mixes for deep $\mathrm{CO}_{2}$ mitigation in road transport. Nature Climate Change, 10, 809-818. https://doi.org/10.1038/s41558-020-0877-y

Bang, G., Victor, D. G., \& Andresen, S. (2017). California's cap-and-trade system: Diffusion and lessons. Global Environmental Politics, 17, 12-30. https://doi.org/10.1162/GLEP_a_00413

Baranzini, A., van den Bergh, J. C. J. M., Carattini, S., Howarth, R. B., Padilla, E., \& Roca, J. (2017). Carbon pricing in climate policy: Seven reasons, complementary instruments, and political economy considerations. Wires Climate Change, 8, e462. https://doi.org/10.1002/wcc.462

Barbour, E. (2020). Sustainability planning by Metropolitan Planning Organizations: California and national trends. In E. A. Deakin (Ed.), Transportation, land use, and environmental planning (pp. 439-467). Elsevier.

Béland, D. (2007). Ideas and institutional change in social security: Conversion, layering, and policy drift. Social Science Quarterly, 88, 20-38. https://doi.org/10.1111/j.1540-6237.2007.00444.x

Bennear, L. S., \& Stavins, R. N. (2007). Second-best theory and the use of multiple policy instruments. Environmental and Resource Economics, 37, 111-129. https://doi.org/10.1007/s10640-007-9110-y

Berck, P., Braennlund, R., \& Berck, C. S. (2010). Green regulations in California and Sweden. Journal of Natural Resources Policy Research, 3, 49-61. https://doi.org/10.1080/19390459.2011.534633

Bhardwaj, C., Axsen, J., Kern, F., \& McCollum, D. (2020). Why have multiple climate policies for light-duty vehicles? Policy mix rationales, interactions and research gaps. Transportation Research Part A: Policy and Practice, 135, 309-326. https://doi.org/10.1016/j.tra.2020.03.011 
Böhringer, C., \& Rosendahl, K. E. (2010). Green promotes the dirtiest: On the interaction between black and green quotas in energy markets. Journal of Regulatory Economics, 37, 316-325. https://doi.org/10.1007/s1114 9-010-9116-1

Borenstein, S., \& Bushnell, J. (2018). California's carbon cap is not in Jeopardy, because it's not really a cap. Energy Institute at Haas, Stanford University. https://energyathaas.wordpress.com/2018/01/02/californias-carboncap-is-not-in-jeopardy-because-its-not-really-a-cap/

Borenstein, S., Bushnell, J., \& Wolak, F. A. (2017). California's cap-and-trade market through 2030: A preliminary supply/demand analysis (WP 281). Energy Institute at Haas.

Borenstein, S., Bushnell, J., Wolak, F. A., \& Zaragoza-Watkins, M. (2018). Expecting the unexpected: Emissions uncertainty and environmental market design (WP 274R). Energy Institute at Haas.

Borenstein, S., Bushnell, J., Wolak, F. A., \& Zaragoza-Watkins, M. (2019). Expecting the unexpected: Emissions uncertainty and environmental market design. American Economic Review, 109, 3953-3977. https://doi. org/10.1257/aer.20161218

Boyd, B., \& Rabe, B. (2019). Whither Canadian climate policy in the Trump era? In D. Carment \& C. Sands (Eds.), Canada-US relations (pp. 239-260). Springer.

Bradford, H. (2019). Canada: Biofuels Annual 2019 (GAIN Report Number: CA19017). USDA Foreign Agricultural Service.

Brazeau, A. (2021). Why Canada needs a national zero-emission vehicle standard in 2021. Institute for Research on Public Policy. https://policyoptions.irpp.org/magazines/february-2021/why-canada-needs-a-national-zeroemission-vehicle-standard-in-2021

Breetz, H. L. (2017). Regulating carbon emissions from indirect land use change (ILUC): US and California case studies. Environmental Science \& Policy, 77, 25-31. https://doi.org/10.1016/j.envsci.2017.07.016

Breetz, H., Mildenberger, M., \& Stokes, L. (2018). The political logics of clean energy transitions. Business and Politics, 20, 492-522. https://doi.org/10.1017/bap.2018.14

British Columbia. (2020). Provincial inventory 1990-2018. Author. https://www2.gov.bc.ca/gov/content/envir onment/climate-change/data/provincial-inventory

Busch, C. (2017). Oversupply grows in the western climate initiative carbon market. Energy Innovation.

California Air Resources Board. (1998). Staff report: 1998 Zero-emission vehicle biennial program review. Author. https://ww3.arb.ca.gov/msprog/zevprog/98review/staffrpt.pdf

California Air Resources Board. (2000). Staff report: 2000 zero-emission vehicle biennial program review. Author. https://ww3.arb.ca.gov/msprog/zevprog/2000review/execsumm.pdf

California Air Resources Board. (2003). Description and rationale for staff's additional proposed modifications to the January 10, 2003 ZEV regulatory proposal. Author. https://ww3.arb.ca.gov/regact/zev2003/rationale.pdf

California Air Resources Board. (2004). Fact sheet-Climate change emission control regulations. Author. https:// ww3.arb.ca.gov/cc/factsheets/cc_newfs.pdf

California Air Resources Board. (2008). Climate change scoping plan: A framework for change. Author.

California Air Resources Board. (2012). Staff report: Initial statement of reasons for proposed amendments to the California cap on greenhouse gas emissions and market-based compliance mechanisms to allow for the use of compliance instruments issued by linked jurisdictions. Author.

California Air Resources Board. (2016). ZEV regulation tutorial for model years 2018+. Author. https://ww2.arb. ca.gov/resources/documents/zev-regulation-tutorial-model-years-2018

California Air Resources Board. (2017a). California's 2017 climate change scoping plan: The strategy for achieving California's 2030 greenhouse gas target. Author.

California Air Resources Board. (2017b). California's advanced clean cars program midterm review. Author. https:// ww3.arb.ca.gov/msprog/acc/mtr/acc_mtr_finalreport_full.pdf?_ga=2.125570570.1661248149.1567536001 $-1039304084.1547076712$

California Air Resources Board. (2017c). CARB approves plan to meet California's bold climate and air quality goals. Author. https://ww2.arb.ca.gov/news/carb-approves-plan-meet-californias-bold-climate-and-air-quality-goals

California Air Resources Board. (2017d). Final 2017 scoping plan update appendices and modeling information. Author. https://www.arb.ca.gov/cc/scopingplan/meetings/meetings.htm

California Air Resources Board. (2017e). Transportation conformity requirements. Author. https://www.arb.ca.gov/ planning/tsaq/conformity/conformity.htm 
California Air Resources Board. (2018a). 2018 Progress report: California’s sustainable communities and climate protection act. Author.

California Air Resources Board. (2018b). Advanced clean cars program: About. Author. https://ww2.arb.ca.gov/ our-work/programs/advanced-clean-cars-program/about

California Air Resources Board. (2018c). Regional plan targets. Author. https://ww2.arb.ca.gov/our-work/progr ams/sustainable-communities-program/regional-plan-targets

California Air Resources Board. (2018d). ZEV regulation factsheet. Author. https://ww2.arb.ca.gov/resources/factsheets/zev-regulation-factsheet

California Air Resources Board. (2019a). 2019 Edition, California greenhouse gas emission inventory: 2000-2017. Author. https://ww3.arb.ca.gov/cc/inventory/pubs/reports/2000_2016/ghg_inventory_trends_00-16.pdf

California Air Resources Board. (2019b). Final draft sustainable communities strategy program and evaluation guidelines. Author. https://ww2.arb.ca.gov/sites/default/files/2019-03/Draft_SCS_Evaluation_Guidelines_ Report.pdf

California Air Resources Board. (2019c). Low carbon fuel standard. Author. https://www.arb.ca.gov/fuels/lcfs/ lcfs.htm

California Air Resources Board. (2019d). Regulation for the California cap on greenhouse gas emissions and market-based compliance mechanisms (effective date 1 April 2019). In Title 17, California code of regulations, sections 95801-96022. Government of California. https://ww3.arb.ca.gov/cc/capandtrade/capandtrad e/ct_reg_unofficial.pdf

California Air Resources Board. (2019e). States that have adopted California's vehicle standards under section 177 of the federal clean air act (table current as of August 19, 2019). Author. https://ww2.arb.ca.gov/sites/default/ files/2019-03/177-states.pdf

California Air Resources Board. (2020a). California greenhouse gas 2000-2018 emissions trends and indicators report: 2000-2018 GHG emissions trends report data. Author. https://ww3.arb.ca.gov/cc/inventory/pubs/repor ts/2000_2018/2000_2018_ghg_inventory_trends_figures.xlsx

California Air Resources Board. (2020b). Zero-emission vehicle program. Author. https://ww2.arb.ca.gov/ node/2558/about

California Air Resources Board. (2021). LCFS Quarterly Data Spreadsheet (last updated April 30, 2021). Author. https://www.arb.ca.gov/fuels/lcfs/dashboard/quarterlysummary/quarterlysummary_043021.xlsx

Canadian Automobile Association \& Pollution Probe. (2009). Primer on automobile fuel efficiency and emissions. Author.

Canadian Automobile Association-Quebec. (2008). Nouvelles normes d'émission de GES des véhicules neufs: Points saillants. Author. https://www.caaquebec.com/fr/auto/conseils/capsules-conseils/conseil/show/ sujet/nouvelles-normes-demission-de-ges-des-vehicules-neufs-points-saillants/

Canadian Broadcasting Corporation. (2020). Quebec to ban sale of new gas-powered vehicles as of 2035. Author. https://www.cbc.ca/news/canada/montreal/gas-vehicles-ban-electric-quebec-1.5802374

CARB \& MELCC. (2021). California cap-and-trade program and Québec cap-and-trade system February 2021 Joint Auction \#26: Summary results report. California Air Resources Board \& Ministère de l'Environnement et de la Lutte contre les changements climatiques.

CALTRANS. (2016). California sustainable freight action plan. California Department of Transportation. http://dot. ca.gov/hq/tpp/offices/ogm/cs_freight_action_plan/Documents/CSFAP_Main\%20Document_FINAL_07272 016.pdf

Carmody, C. (2019). A guide to emissions trading under the western climate initiative. Centre for International Governance Innovation.

Carrillo, J. (2004). NAFTA: The process of regional integration of motor vehicle production. In J. Carrillo, Y. Lung, \& R. van Tulder (Eds.), Cars, carriers of regionalism? (pp. 104-117). Palgrave Macmillan.

Carroll, P., Caulfield, B., \& Ahern, A. (2019). Measuring the potential emission reductions from a shift towards public transport. Transportation Research Part D: Transport and Environment, 73, 338-351. https://doi. org/10.1016/j.trd.2019.07.010

CCI. (2021). Annual report to the legislature on California climate investments using cap-and-trade auction proceeds. State of California.

Clean Energy Canada. (2020). What is a 'zero-emission vehicle standard' and why does Canada need one?. Author. 
Cloarec, B., \& Purdon, M. (2018). Evolution of the joint carbon market: Impact of the entry and potential exit of Ontario. Institut québécois du carbone.

Collantes, G., \& Sperling, D. (2008). The origin of California's zero emission vehicle mandate. Transportation Research Part A: Policy and Practice, 42, 1302-1313. https://doi.org/10.1016/j.tra.2008.05.007

Communauté métropolitaine de Montréal. (2019). Communauté métropolitaine de Montréal-À propos. Author. http://cmm.qc.ca/a-propos

Conseil de gestion du Fonds vert. (2018). Fonds vert: Cadre de Gestion. Author.

Cullenward, D. (2014). Leakage in California's carbon market. The Electricity Journal, 27, 36-48. https://doi. org/10.1016/j.tej.2014.09.014

Cullenward, D., \& Coghlan, A. (2016). Structural oversupply and credibility in California's carbon market. The Electricity Journal, 29, 7-14. https://doi.org/10.1016/j.tej.2016.06.006

Cullenward, D., \& Victor, D. G. (2020). Making climate policy work. John Wiley \& Sons.

Diodati, M.-H., \& Purdon, M. (2016). Political uncertainty or carbon leakage? State of the California-Quebec carbon market after the August 2016 auction. IQCarbone Research Note 2016-2. Institut québécois du carbone.

Duffy, J. (2019). Low carbon fuel standard-Presentation at the Joint Workshop of the Joint Clean Climate Transport Research Partnership (JCCTRP) \& California Climate Policy Modeling Forum (CCPM), 27 February 2019, UC Davis. Joint Clean Climate Transport Research Partnership (JCCTRP).

Ecofiscal Commission. (2019). Bridging the gap: Real options for meeting Canada's 2030 GHG target. Canada's Ecofiscal Commission.

EIA. (2021). Crude oil production. US Energy Information Administration. https://www.eia.gov/dnav/pet/pet_ crd_crpdn_adc_mbbl_a.htm

Ellerman, A. D., Convery, F. J., \& De Perthuis, C. (2010). Pricing carbon: The European Union emissions trading scheme. Cambridge University Press.

Environment and Climate Change Canada. (2017). Clean fuel standard: Discussion Paper. Author.

Environment and Climate Change Canada. (2019a). Clean fuel standard: Proposed regulatory approach. Author. https://www.canada.ca/content/dam/eccc/documents/pdf/climate-change/pricing-pollution/Clean -fuel-standard-proposed-regulatory-approach.pdf

Environment and Climate Change Canada. (2019b). National inventory report 1990-2019_Greenhouse gas sources and sinks in Canada, Table A11-10: 1990-2017 GHG emission summary for Quebec. Author.

Environment and Climate Change Canada. (2020). A healthy environment and a health economy: Canada's strengthened climate plan to create jobs and support people, communities and the planet. Author.

Farrell, A. E., Sperling, D., Arons, S., Brandt, A., Delucchi, M., Eggert, A., Farrell, A., Haya, B., Hughes, J., \& Jenkins, B. (2007). A low-carbon fuel standard for California Part 1: Technical analysis. UC Berkeley, Transportation Sustainability Research Center.

Fern, D. F. (1997). The crafting of the national low-emission vehicle program: A private contract theory of public rulemaking. UCLA Journal of Environmental Law and Policy, 16, 227.

Fischer, C., \& Preonas, L. (2010). Combining policies for renewable energy: Is the whole less than the sum of its parts? International Review of Environmental and Resource Economics, 4, 51-92. https://doi. org/10.1561/101.00000030

Fischer, C., Preonas, L., \& Newell, R. G. (2017). Environmental and technology policy options in the electricity sector: Are we deploying too many? Journal of the Association of Environmental and Resource Economists, 4 , 959-984. https://doi.org/10.1086/692507

Fletcher, R. (2019). CAQ government aims to reform management of Quebec's Green Fund, Global News, Montreal. https://globalnews.ca/news/6109769/caq-government-green-fund-reform/

Flyvbjerg, B. (2006). Five misunderstandings about case-study research. Qualitative Inquiry, 12, 219-245. https:// doi.org/10.1177/1077800405284363

Gouvernement du Québec. (2019) Draft Regulations: Regulation respecting the minimum volume of renewable fuel in gasoline and diesel fuel, in Gazette Officiele du Québec, October 2, 2019, Vol 151, No 402629 , Government of Quebec, Québec. http://www2.publicationsduquebec.gouv.qc.ca/dynamicSearch/telec harge.php?type $=1 \&$ file $=104101$. df

Gouvernement du Québec. (2020a). Plan pour une économie verte 2030: Plan de Mise en Ouevre 2021-2026. Author. https://cdn-contenu.quebec.ca/cdn-contenu/adm/min/environnement/publications-adm/plan-economieverte/plan-mise-oeuvre-2021-2026.pdf?1605824455 
Gouvernement du Québec (2020b). Plan pour une économie verte 2030: Politique-Cadre d'Électrification et de Lutte Contre les Changements Climatiques. Author. https://cdn-contenu.quebec.ca/cdn-contenu/adm/min/envir onnement/publications-adm/plan-economie-verte/plan-economie-verte-2030.pdf?1605540555

Government of Canada. (2016). Pan-Canadian framework on clean growth and climate change. Author.

Government of Canada. (2018). Guidance on the pan-Canadian carbon pollution pricing benchmark. Author. https://www.canada.ca/en/services/environment/weather/climatechange/pan-canadian-framework/guida nce-carbon-pollution-pricing-benchmark.html

Government of Canada. (2020). Canada Gazette, Part I, Volume 154, Number 51: Clean fuel regulations. Author. https://canadagazette.gc.ca/rp-pr/p1/2020/2020-12-19/html/reg2-eng.html

Government of Quebec. (2018). A snapshot of the zero emission vehicle (ZEV) standard. Author. http://www.mddel cc.gouv.qc.ca/changementsclimatiques/vze/feuillet-vze-reglement-en.pdf

Grandoni, D., Siddiqui, F., \& Dennis, B. (2020). California to phase out sales of new gas-powered cars by 2035. Washington Post. https://www.washingtonpost.com/climate-environment/2020/09/23/california-elect ric-cars/

Hanemann, W. M. (2007). How California came to pass AB 32, the Global Warming Solutions Act of 2006. Department of Agricultural \& Resource Economics, UCB.

High-Level Commission on Carbon Prices. 2017. Report of the high-level commission on carbon prices. Carbon Pricing Leadership Coalition, World Bank, Washington DC.

Hochstetler, K. (2020). Political economies of energy transition: Wind and solar power in Brazil and South Africa. Cambridge University Press.

Hood, C. C., \& Margetts, H. Z. (2007). The tools of government in the digital age. Macmillan International Higher Education.

Houle, D., Lachapelle, E., \& Purdon, M. (2015). The comparative politics of sub-federal cap-and-trade: Implementing the western climate initiative. Global Environmental Politics, 15, 49-73. https://doi. org/10.1162/GLEP_a_00311

Hydro-Québec. (2018). Comparison of electricity prices in major North American cities. Author.

Independent Emissoins Market Advisory Committee. (2018). 2018 Annual Report of the Independent Emissions Market Advisory Committee. Independent Emissoins Market Advisory Committee (IEMAC), California EPA.

Infrastucture Canada. (2018). Investing in Canada: \$180+ billion infrastructure plan over 12 years. Author. https:// www.infrastructure.gc.ca/plan/about-invest-apropos-eng.html

Infrastucture Canada. (2019a). Climate lens-General guidance. Author. https://www.infrastructure.gc.ca/pub/ other-autre/cl-occ-eng.html

Infrastucture Canada. (2019b). Investing in Canada plan. Author. https://www.infrastructure.gc.ca/plan/about -invest-apropos-eng.html

Institute of Local Government. (2015). The basics of SB 375. Author. www.ca-ilg.org/post/basics-sb-375

International Carbon Action Partnership. (2021). Washington state legislature passes cap-and-trade program. Author.

Jaccard, M. (2020). The citizen's guide to climate success: Overcoming myths that hinder progress. Cambridge University Press.

Jenkins, J. D., Stokes, L., \& Wagner, G. (2020). Carbon pricing and innovation in a world of political constraints. Workshop Report. https://gwagner.com/wp-content/uploads/Jenkins-Stokes-Wagner-2020-Carbon-PricingWorkshop.pdf

Kahn, D. (2007). California adopts low-carbon fuel standard. Scientific American. https://www.scientificamerican. com/article/california-adopts-low-car/

Kingdon, J. W. (1984). Agendas, alternatives, and public policies. Little, Brown Boston.

Klenert, D., Mattauch, L., Combet, E., Edenhofer, O., Hepburn, C., Rafaty, R., \& Stern, N. (2018). Making carbon pricing work for citizens. Nature Climate Change, 8, 669-677. https://doi.org/10.1038/s41558-018-0201-2

Kyriazis, J. (2017). Equivalency of carbon pricing systems under the Pan-Canadian framework. Institut québécois du carbone (IQCarbone). http://www.iqcarbone.org/equivalency-of-carbon-pricing-systems-under -the-pan-canadian-framework/

La Presse. (2015). Québec confirme sa cible de réduction des gaz à effet de serre. Author. https://www.lapresse. $\mathrm{ca} /$ environnement/dossiers/changements-climatiques/201511/27/01-4925512-quebec-confirme-sa-cible -de-reduction-des-gaz-a-effet-de-serre.php 
Lachapelle, E., \& Kiss, S. (2019). Opposition to carbon pricing and right-wing populism: Ontario's 2018 general election. Environmental Politics, 28, 970-976. https://doi.org/10.1080/09644016.2019.1608659

Lachapelle, E., Papy, J., Pineau, P.-O., \& Trudeau, H. (2017). Enquête sur les entreprises touchées par le système de plafonnement et d'échange de droits d'émission de gaz à effet de serre au Québec (SPEDE). Centre interuniversitaire de recherche en analyse des organisations.

Langue, R., \& Hafsi, T. (2010). Société d'État? Pourquoi pas? Les Secrets de la Réussite d'Hydro-Québec. Presses de l'Université du Québec.

Lepitzki, J., \& Axsen, J. (2018). The role of a low carbon fuel standard in achieving long-term GHG reduction targets. Energy Policy, 119, 423-440. https://doi.org/10.1016/j.enpol.2018.03.067

Mascher, S. (2018). Striving for equivalency across the Alberta, British Columbia, Ontario and Québec carbon pricing systems: The Pan-Canadian carbon pricing benchmark. Climate Policy, 18, 1012-1027. https://doi. org/10.1080/14693062.2018.1470489

McCarthy, S., \& Giovannetti, J. (2019, June 13). Ottawa vows to freeze carbon tax after 2022 as it moves to impose levy on Alberta in January. The Globe and Mail. https://www.theglobeandmail.com/business/article-feder al-carbon-tax-would-have-to-double-to-meet-canadas-climate/

McCrary, M. D., Panzer, D. E., \& Pierson, M. O. (2003). Oil and gas operations offshore California: Status, risks, and safety. Marine Ornithology, 31, 43-49.

Meckling, J. (2017). The developmental state in global regulation: Economic change and climate policy. European Journal of International Relations, 24, 58-81. https://doi.org/10.1177/1354066117700966

Meckling, J., Kelsey, N., Biber, E., \& Zysman, J. (2015). Winning coalitions for climate policy. Science, 349, 11701171. https://doi.org/10.1126/science.aab1336

Meckling, J., \& Nahm, J. (2018). The power of process: State capacity and climate policy. Governance, 31, 741-757. https://doi.org/10.1111/gove.12338

Meckling, J., Sterner, T., \& Wagner, G. (2017). Policy sequencing toward decarbonization. Nature Energy, 2, 918922. https://doi.org/10.1038/s41560-017-0025-8

Mildenberger, M. (2019). Support for climate unilateralism. Nature Climate Change, 9, 187-188. https://doi. org/10.1038/s41558-019-0416-x

Ministère de l'Environnement et de la Lutte contre les changements climatiques. (2019). Motor vehicle greenhouse gas emissions. Author. http://www.environnement.gouv.qc.ca/changements/ges-en/reglement.htm

Ministère de l'Environnement et de la Lutte contre les changements climatiques. (2020a). Auction proceeds allocated to the electrification and climate change fund. Author. http://www.environnement.gouv.qc.ca/chang ements/carbone/revenus-en.htm

Ministère de l'Environnement et de la Lutte contre les changements climatiques. (2020b). Inventaire québécois des émissions de gaz a effet de serre en 2018 et leur évolution depuis 1990. Author.

Ministère de l'Énergie et des ressources naturelles. (2016). Politique énergétique 2030. Author.

Ministère des Finances du Québec. (2017). Impacts économiques du système de plafonnement et d'échange de droits d'émission de gaz à effet de serre du Québec. Author.

Ministère du Développement durable, de l'Environnement et de la Lutte contre les Changements Climatiques. (2008). Quebec and climate change: 2006-2012 action plan. Minister of Sustainable Development, Environment and Parks.

Ministère du Développement durable, de l'Environnement et de la Lutte contre les Changements Climatiques. (2018). Plan d'action 2013-2020 sur les changements climatiques: Bilan Mi-Parcours 2017-2018, Author.

Next 10. (2018). The road ahead for zero-emission vehicles in California: Market trends \& policy analysis. Author. http://next10.org/sites/default/files/ca-zev-brief.pdf

Oster, C. (2019). Fuel efficiency standards-California vs. the feds (how we got here, and what comes next). Eno Center for Transportation. https://www.enotrans.org/article/fuel-efficiency-standards-california-vs-the-feds -how-we-got-here-and-what-comes-next/

Pahle, M., Burtraw, D., Flachsland, C., Kelsey, N., Biber, E., Meckling, J., Edenhofer, O., \& Zysman, J. (2018). Sequencing to ratchet up climate policy stringency. Nature Climate Change, 8, 861-867. https://doi. org/10.1038/s41558-018-0287-6

PBO. (2020). Carbon pricing for the Paris target: Closing the gap with output-based pricing. Office of the Parliamentary Budget Officer. 
Peesapati, S. (2018). California's next environmental frontier: Climate justice leadership. Hastings Environmental Law Journal, 24, 121.

Peters, B. G., \& Zittoun, P. (2016). Introduction. In B. G. Peters \& P. Zittoun (Eds.), Contemporary approaches to public policy: Theories, controversies and perspectives (pp. 1-14). Palgrave Macmillan.

Posada, F., Sharpe, B., Isenstadt, A., \& German, J. (2018). Assessing Canada's 2025 passenger vehicle greenhouse gas standards: Technology deployment and costs. International Council on Clean Transportation.

Pretis, F. (2019). Does a carbon tax reduce $\mathrm{CO}_{2}$ emissions? Evidence from British Columbia. https://ssrn.com/abstr act $=3329512$

Purdon, M., Houle, D., \& Lachapelle, E. (2014). Mapping the political economy of California and Quebec's cap-andtrade systems. Sustainable Prosperity.

Purdon, M., \& Sinclair-Desgagné, N. (2015). Les retombées économiques prévues du marché du carbone conjoint de Californie et du Québec. In Notes \& analyses sur les États-Unis/on the USA (Vol. 29). Centre d'études et de recherches internationales, Université de Montréal, Montreal. https://cerium.umontreal.ca/public/FAS/ cerium/Images/4_nouvelles_evenements/legacy/notesanalyses029.pdf

Rabe, B. (2018). Can we price carbon?. MIT Press.

Reuters. (2021). California governor seeks end to oil drilling in state by 2045. Author. https://www.reuters.com/ business/energy/california-governor-seeks-end-oil-drilling-state-by-2045-2021-04-23/

Roch, F., \& Papy, J. (2019). L'Entente de liaison des marchés du carbone de la Western Climate Initiative: Enjeux institutionnels et juridiques pour le Québec. Revue Générale de Droit, 49, 67-109.

Rodier, C. (2009). Review of international modeling literature: Transit, land use, and auto pricing strategies to reduce vehicle miles traveled and greenhouse gas emissions. Transportation Research Record, 2132, 1-12. https://doi.org/10.3141/2132-01

Rubin, E. S., Azevedo, I. M., Jaramillo, P., \& Yeh, S. (2015). A review of learning rates for electricity supply technologies. Energy Policy, 86, 198-218. https://doi.org/10.1016/j.enpol.2015.06.011

Salamon, L. M. (2002). The tools of government: A guide to the new governance. Oxford University Press.

Schatzki, T., \& Stavins, R. N. (2018a). GHG cap-and-trade: Implications for effective and efficient climate policy in Oregon. Harvard Project on Climate Agreements.

Schatzki, T., \& Stavins, R. N. (2018b). Key issues facing California's GHG cap-and-trade system for 2021-2030, Discussion Paper 2018-90. Harvard Project on Climate Agreements.

Sciara, G.-C. (2017). Metropolitan transportation planning: Lessons from the past, institutions for the future. Journal of the American Planning Association, 83, 262-276. https://doi.org/10.1080/01944 363.2017.1322526

Sciara, G.-C., \& Handy, S. (2017). Regional transportation planning, 4th Edition. In G. Giuliano \& S. Hanson (Eds.), The geography of urban transportation (pp. 139-163). Guilford Press.

Statt, N. (2019, May 30). British Columbia passes emissions law banning sale of gas-powered cars by 2040. The Verge. https://www.theverge.com/2019/2015/2030/18646486/british-columbia-zero-emissions-vehicles-actban-gas-powered-cars-climate-change

Steenblik, R. (2007). Biofuels at what cost? Government support for ethanol and biodiesel in selected OECD countries synthesis of reports addressing subsidies for biofuels in Australia, Canada, the European Union, Switzerland and United States. The Global Subsidies Initiative, GSI.

Stokes, L. C. (2020). Short circuiting policy: Interest groups and the battle over clean energy and climate policy in the American States. Oxford University Press.

Stokes, L. C., \& Breetz, H. L. (2018). Politics in the U.S. energy transition: Case studies of solar, wind, biofuels and electric vehicles policy. Energy Policy, 113, 76-86. https://doi.org/10.1016/j.enpol.2017.10.057

Thelen, K. (2004). How institutions evolve. Cambridge University Press.

Transport Canada. (2017). Government of Canada to develop a national zero-emissions vehicle strategy by 2018. Government of Canada. https://www.canada.ca/en/transport-canada/news/2017/05/government_of_canad atodevelopanationalzero-emissionsvehiclestrat.html

TransportPolicy.Net. (2018). Canada: Light-Duty Fuel Consumption and GHG. ICCT \& DieselNet. https://www. transportpolicy.net/standard/canada-light-duty-fuel-consumption-and-ghg/

Trudeau, H. (2018). Le système de plafonnement et d'échange de droits d'émission de gaz à effet de serre : L'expérience Québécoise. Institut canadien du droit des ressources Laval. 
van den Bergh, J., \& Botzen, W. (2020). Low-carbon transition is improbable without carbon pricing. Proceedings of the National Academy of Sciences, 117, 23219-23220. https://doi.org/10.1073/pnas.2010380117

Ville de Montréal. (2018). Suivi du Plan de réduction des émissions de gaz à effet de serre de la collectivité montréalaise 2013-2020. Author.

Ville de Montréal. (2019). Émissions de gaz à effet de serre de la collectivité montréalaise: Inventaire 2015. Author.

Vogel, D. (1995). Trading up: Consumer and environmental regulation in a global economy. Harvard University Press.

Vogel, D. (2018). California Greenin': How the golden state became an environmental leader. Princeton University Press.

WCI Economic Modeling Team. (2012). Discussion draft economic analysis supporting the cap-and-trade programCalifornia and Québec. Western Climate Initiative.

Weikle, B. (2019, June 27). Canada and California sign deal to cut vehicle emissions. CBC News. https://www.cbc. ca/news/business/canada-california-vehicle-emissions-2011.5190619

Weiss, M., Junginger, M., Patel, M. K., \& Blok, K. (2010). A review of experience curve analyses for energy demand technologies. Technological Forecasting and Social Change, 77, 411-428. https://doi.org/10.1016/j.techf ore.2009.10.009

Wesseling, J. H., Farla, J. C. M., Sperling, D., \& Hekkert, M. P. (2014). Car manufacturers' changing political strategies on the ZEV mandate. Transportation Research Part D: Transport and Environment, 33, 196-209. https:// doi.org/10.1016/j.trd.2014.06.006

Whitmore, J., \& Pineau, P.-O. (2018). État de l'énergie au Québec 2019. Chaire de gestion du secteur de l'énergie, HEC Montréal.

Witcover, J. (2018). Status review of California's low carbon fuel standard, 2011-2018 Q1, UCD-ITS-RR-18-25. Institute of Transportation Studies, University of California, Davis, Research Report.

Wolf, J. F., \& Fenwick, M. (2003). How metropolitan planning organizations incorporate land-use issues in regional transportation planning. State and Local Government Review, 35, 123-131. https://doi.org/10.1177/01603 23X0303500205

Wolinetz, M., Hein, M., \& Moawad, B. (2019). Biofuels in Canada 2019. Navius Research.

Wu, X., Ramesh, M., \& Howlett, M. (2015). Policy capacity: A conceptual framework for understanding policy competences and capabilities. Policy and Society, 34, 165-171. https://doi.org/10.1016/j.polsoc.2015.09.001

Yang, C., Yeh, S., Zakerinia, S., Ramea, K., \& McCollum, D. (2015). Achieving California's 80\% greenhouse gas reduction target in 2050: Technology, policy and scenario analysis using CA-TIMES energy economic systems model. Energy Policy, 77, 118-130. https://doi.org/10.1016/j.enpol.2014.12.006

Yang, Y., Hagerty, M., Palmarozzo, A., Celebi, M., Chupka, M., \& Sheffield, H. (2017). The future of cap-and-trade program in California: Will low GHG prices last forever?. The Brattle Group.

Yeh, S., Witcover, J., Lade, G. E., \& Sperling, D. (2016). A review of low carbon fuel policies: Principles, program status and future directions. Energy Policy, 97, 220-234. https://doi.org/10.1016/j.enpol.2016.07.029

\section{AUTHOR BIOGRAPHIES}

Mark Purdon is an Assistant Professor at the École des sciences de la gestion at the Université du Québec à Montréal (ESG UQAM) where he holds the Chaire sur la décarbonisation and directs the Joint Clean Climate Transport Research Partnership (JCCTRP). His research focuses on comparative climate change politics and policy.

Julie Witcover is an Assistant Project Scientist at the Institute of Transportation Studies and the Policy Institute for Energy, Environment, and the Economy, at the University of California, Davis. Her research focuses on low carbon fuel policy and industry responses to it.

Colin Murphy is the Deputy Director of the University of California, Davis Policy Institute for Energy, Environment, and the Economy. His research focuses on climate policy, clean fuels standards, carbon markets, air quality, and sustainable transportation. 
Sonya Ziaja is an assistant professor at the University of Baltimore School of Law. Her research interests focus on the overlapping areas of environmental governance and law, technology and society. Her approach to these questions draws on her interdisciplinary background in geography, water policy and law, as well as her practical knowledge of energy regulation.

Mark Winfield is a Professor of Environmental and Urban Change at York University. He is also Co-Chair of the Faculty's Sustainable Energy Initiative, and has published articles, book chapters and reports on a wide range of climate change, environment and energy law and policy topics.

Genevieve Giuliano is the Margaret and John Ferraro Chair in Effective Local Government and Director, METRANS Transportation Consortium. Her research focuses on transportation policy and planning.

Charles Séguin is an Associate Professor at the Department of Economics of the École des sciences de la gestion at the Université du Québec à Montréal (ESG UQAM). He is also member of CIRANO and CIRODD. His research focuses on environmental pricing policies and natural resources management.

Colleen Kaiser is a post-doctoral fellow at the University of Ottawa, Smart Prosperity Institute. Their research focuses on climate change governance, especially decarbonization of the transport sector, and increasing regulatory agility to drive clean growth.

Jacques Papy is assistant professor at the Faculté de sciences politiques et de droit at the Université du Québec à Montréal. His research focuses on the regulation of carbon markets.

Lewis Fulton is the Director of the Sustainable Transportation Energy Pathways Program at UC Davis, Institute of Transportation Studies. Lewis leads research on transitions to low carbon transportation systems and undertakes specific studies of electric and hydrogen vehicle futures.

How to cite this article: Purdon, M., Witcover, J., Murphy, C., Ziaja, S., Winfield, M., Giuliano, G., Séguin, C., Kaiser, C., Papy, J., \& Fulton, L. (2021). Climate and transportation policy sequencing in California and Quebec. Review of Policy Research, 00, 1-35. https://doi.org/10.1111/ropr.12440 